\title{
El INTERÉS POR EL PASADO EN LA ANTIGÜEDAD
}

\author{
Interest in the past in Ancient times
}

Javier Verdugo Santos*

Junta de Andalucía

Recibido: 13/09/2016

Revisado: 24/02/2017
Aceptado: $19 / 05 / 2017$

Publicado: 23/06/2017

\section{RESUMO}

Los sucesos del pasado son transmitidos oralmente en forma de mitos. A esta fase le sucede una segunda basada en el conocimiento y análisis contrastado de los sucesos reales acaecidos. Surge así la historia, la etnología y el viaje arqueológico o "Periégesis". Fruto de esa observación asistimos a un interés por determinadas construcciones que están cargadas de admiración, las Septem Orbis Spectaculis. Aparece también un interés por los objetos como botín de guerra con una doble intención: religiosa, consistente en apropiarse de las divinidades y someterlas a las propias y económica, por su estética y valor. Los objetos son exhibidos ante el pueblo vencedor que en el caso de Roma forman parte de su propio patrimonio como vemos en los relieves del Arco de Tito.

\section{Palabras Clave}

Arqueología; educación; monumento; maravilla.

\section{Abstract}

Past events are transmitted orally in the form of myths. This phase is followed by a second based on the proven knowledge and analysis of the actual events that occurred This raises the history, ethnology and archeology trip or "Periegesis". The result of this observation witnessing an interest in certain buildings that are full of admiration for the Septem Orbis Spectaculis. Religious, consisting divinities appropriate and subject to the specific and economic, for its aesthetic value: an interest in the objects as spoils of war with a double intention also appears. Objects are displayed to the victorious people in the case of Rome they are part of their own heritage as seen in the reliefs on the Arch of Titus.

\section{KEY WORDS}

Archaeology; time; education; monument; wonder.

* Doctor por la Universidad de Huelva (UHU). Licenciado en Derecho Público y Licenciado en Geografía e Historia por la Universidad de Sevilla (USE). Arqueólogo Conservador de Patrimonio de la Junta de Andalucía. Miembro del Comité Español de ICOMOS.

fjavier.verdugo@juntadeandalucia.es 


\section{LA IDEA DEL TIEMPO Y DEL PASADO.}

Como afirma Le Goff $(1991,11)$ el devenir de las cosas, los acontecimientos, la vejez y la muerte; la necesidad de ordenar los sucesos en una escala cronológica y continuada, llevó a la Humanidad a inventar un concepto, una abstracción, que hoy consideramos consustancial a nuestra existencia, nos referimos al tiempo. La idea del tiempo nos lleva a tres grados: el presente, el pasado y el futuro. El pasado, ligado a la idea de memoria, es concebido en las fases tempranas de la historia como un fragmento del tiempo, unido a ideas felices o catastróficas a veces dividido en edades, siguiendo un cierto orden. De este modo casi todas las religiones o mitologías sitúan al comienzo de los tiempos una "edad de oro", y otras, como el cristianismo coloca una etapa escatológica al final de los tiempos, es decir en el futuro último (Eliade, 1972, 18).

En el mundo grecorromano, hay una fuerte creencia en una "edad de oro primitiva", que tal vez tenga algo que ver con una percepción mítica de un hecho real: el hundimiento de la espléndida Edad del Bronce creto-micénica. Este suceso tuvo un preludio: los terremotos y maremotos, que alrededor del 1400 a.C., asolaron la zona y que trajo la destrucción de Thera, tal vez recogida en el mito platónico de la Atlántida, y que fue el detonante de la caída de Creta. Estos movimientos telúricos se sintieron en Siria y en el norte de África. Algunos textos dramáticos egipcios de la XVIII dinastía parecen hacerse eco de este desastre: "La confusión embargaba los ojos...no hubo salida del palacio por espacio de nueve días. Esos nueve días fueron de violencia y tempestad. Nadie...podía ver la cara del que tenía al lado"(Kostof, 1988, 198). Después de esta catástrofe, Creta palideció, pero lo peor estaba por llegar. Dos siglos más tarde la amenaza vino por tierra, por la frontera norte de los reinos micénicos del continente: una tribu griega, los dorios, con sus espadas de hierro, conquista todas las ciudades micénicas. De repente todo se oscureció. Comenzó a sentirse un sentimiento de que algo muy hermoso había sucumbido, que existió una edad de oro anterior en la que los hombres eran gobernados por príncipes héroes y los dioses habitaban en las ciudades.

Dos poetas rememorarán esta edad mítica y dorada: Homero y Hesíodo. En la época en la que Homero escribe nada queda del mundo micénico, pero el recuerdo se había mantenido. Algunos detalles anacrónicos dan fe de esta falta de información, cómo cuando nos dice que los príncipes eran incinerados - ritual éste introducido por los dorios-, y no inhumados. Homero por ser el evocador del pasado áureo, se convirtió en el poeta nacional de los griegos, como mucho tiempo después ocurrirá con Virgilio y Dante en el tardo medioevo italiano. Homero fue para los griegos un "símbolo preeminente de nacionalidad, la autoridad intachable de su historia primitiva y una figura decisiva en la creación de su Panteón” (Finley, 1978, 13). Homero es la memoria de los griegos, y también de nosotros mismos. Era un narrador de mitos y leyendas. Finley $(1978,22)$ considera que el mito está presente entre los griegos desde muchos siglos antes de Homero, y era una actividad del más alto nivel social, que se hacía llegar siempre a través de la palabra y en un acto lleno de ceremonial. El mito, continua Finley, tiene por temática esencial la acción, no son ideas, credos o representaciones simbólicas, sino acontecimientos, aventuras, amores, casamientos y muertes. El mito, en las mentes arcaicas, se considera algo cierto, que sucedió. Como afirma Kirk (2002:31) los mitos son, por un lado, buenas historias y, por otro, portadores de mensajes importantes sobre la vida en general y la vida en sociedad en particular. Los poemas homéricos entretenían a la audiencia con relatos del pasado y los oyentes tenían el convencimiento de que aquello había sucedido en realidad. Jenófanes o el propio Platón se lamentarán de la influencia perniciosa de Homero entre los griegos, y rechazarán el sentido tradicional del mito expresado por aquel. Sobre todo Platón, quien refutará no la veracidad de la historia contada por el poeta sino sus conceptos de justicia y de los dioses, del bien y del mal (Finley, 1978, 22).

Por su parte, Hesíodo, nos habla de edades míticas en su obra Los trabajos y los días, escrita a mediados del siglo VII a.C. Hesíodo mezcla dos ideas, de un lado, el mito de las cuatro edades diferenciadas por nombres de metales y de otro, la leyenda de una edad de héroes, que él coloca entre la tercera y la cuarta (Le Goff, 1991, 19). La primera de ellas es la edad de oro, la edad de la felicidad primitiva: "Una estirpe áurea de hombres mortales crearon en los primeros tiempos los inmortales que tienen la morada sobre el Olimpo".

Las otras edades que Hesíodo recoge, están marcadas por la decadencia. La segunda edad, la de la plata: "Luego, una segunda estirpe, muy inferior, crearon en un tiempo sucesivo los habitantes de las moradas olímpicas: una estirpe argéntea, no seme- 
jante a la áurea, ni en su aspecto, ni en su mente [...] ni querían venerar a los dioses inmortales, ni cumplir sacrificios sobre los santos altares de los bienaventurados, que es piadoso deber de los hombres [...]. Y a éstos, con el tiempo Zeus Cronida los sepultó”.

La tercera, de bronce: "Entonces el padre Zeus creó otra estirpe de hombres mortales -la tercera, de bronce-, en nada semejante a aquélla argentea [...] a la que le gustaban las obras funestas de Ares [...] Tenían armas broncíneas y de bronce sus casas, y con el bronce trabajaban; aún no existía el negro hierro, Y éstos, domados por sus propias manos, marcharon a la escuálida morada del terrible Hades".

La cuarta, de hierro: "Luego, iquiera el cielo que no me haya tocado vivir junto a los hombres de la quinta estirpe, sino haber muerto antes, o haber nacido después! Porque ahora, en verdad, es la edad del hierro; ni nunca los hombres cesarán en el día de fatiga y de miseria, y en la noche de destruirse, y los dioses les darán graves angustias". Con este texto de Hesíodo se inician las edades míticas, con una raza áurea que representa el estado de máxima felicidad. Las otras razas serán sinónimo de decadencia. Según Le Goff (1991, 20), Hesíodo introduce otra raza de hombres entre la de bronce (Micenas?) y la de hierro (dorios?), que procede de otro mito, la raza de los héroes: "Nuevamente Zeus Cronida creó otra estirpe sobre la tierra nutricia de muchos -la cuarta, más justa y más buena, la estirpe divina de los héroes, que son llamados semidioses[... habitan, con el ánimo desprovisto de preocupaciones, en las islas de los Bienaventurados junto al océano de vértices profundos; ellos los héroes venerados, para quienes tres veces el año la tierra dadora de presentes les proporciona abundantes y agradables frutos".

En la narración de Hesíodo hay ciertamente una edad de oro, que se sitúa en el pasado más remoto y a partir de ella hay una decadencia, pero también se observa un deseo de mejorar después de la quinta estirpe -hierro-, ya que Hesíodo se lamenta de haber "muerto demasiado tarde o nacido demasiado temprano"; Le Goff $(1991,20)$ ve en la obra de Hesíodo una intención de volver a la edad de oro, y lejos de desesperarse con las dificultades de la "edad de hierro", en la que le ha tocado vivir, hace apología de la creatividad, del esfuerzo y del trabajo del hombre.

Esta fábula de la decadencia y caída del hombre ha sido contada de diferentes formas. Según Finley $(1978,27)$ la versión de las cuatro edades, cuatro etapas que apartan cada vez más al hombre de su origen, puede ser iranio, y cuando es recibida en Grecia, los griegos que ya tenían la concepción de una edad de héroes, la modifican, insertándola en la serie de los metales.

Ahora bien, isignifica esto que Homero o Hesíodo tuviesen interés por la Historia, tal como la concebimos hoy? Según Finley (1978, 28-29) de ningún modo. No hay referencias históricas ni en la Ilíada ni en los poemas de Hesíodo. La guerra de Troya es sólo un pretexto o un contexto para exaltar el honor y la gloria. Por tanto no estamos ante hechos históricos narrados sino ante un poema que recoge un mito heroico. En el symposion arcaico, lugar de encuentro de los varones aristócratas, se mezclaba el vino y se intercambiaban relatos de todo tipo, entre ellos los patrióticos y mitológicos, en los que no faltaban las referencias al pasado (Buxton, 2000, 39). A partir del siglo $\mathrm{V}$ aunque el symposion siguió actuando como referente en el ámbito o núcleo aristocrático, convive con otros espacios para el intercambio social que de acuerdo con los nuevos principios políticos e ideológicos de la ciudad-estado podemos calificar de acuerdo con Buxton $(2000,41)$ de "públicos" o "cívicos", donde el mito convertido en tragedia y el pasado se comunica por medio de los espectáculos teatrales de los certámenes o en las festividades de las Grandes Dionisias. De este modo la gente se familiarizaba con los personajes de ese pasado con los que buscaba identificarse.

Otra cuestión que despertó un gran interés entre los griegos fue la genealogía (Waters, 1966, 24-25). Estaban interesados en su ascendencia. Ello les hizo volverse hacia el pasado. Comenzaron a realizar historia de ciudades, como la "Descripción de Samos" de Eudón o Dioniso de Mileto y su conciudadano Cadmo que narraron la historia de esa ciudad, y la más importante de ellas que se convirtió en la fuente de Heródoto que fue la "Descripción de Lidia" de Jantes.

La genealogía era transmitida en su totalidad por transmisión oral, y tenía una gran importancia pues el único método que existía de fechar era a través de lista de antepasados, tradiciones familiares o funcionarios políticos o religiosos. Las generaciones aparecen como medidas de tiempo.

\section{DE LA PAIDEIA A LA HUMANITAS.}

La civilización de la paideia, siguiendo a Marrou (1985, 130-140, 215-232) es la constituida por la educación helenística, fruto de una evolución 
desde la Grecia arcaica. Es la consecuencia de las conquistas de Alejandro que extendieron, por gran parte del Mediterráneo y el Oriente, el modo de vida y de pensar de los griegos. Fue la educación vigente en todo Imperio romano y su epilogo bizantino. La educación romana es, por tanto, una adaptación a la educación helenística, y pone en su centro a la cultura, entendida como actitud ante la vida, la areté y la virtus romana. La paideia es traducida por Varrón y Cicerón como humanitas (Aulo Gelio, XIII, 16,1). Una cultura universal, ecuménica que incorpora elementos multiculturales, pero que a la vez supone una recreación griega de esos elementos diversos, de modo que ya no será la ciudad el único marco para la civilización, sino que allí donde se encuentre un griego o un romano helenizado aparecerá una cultura, un modo de vida con sus escuelas, gimnasios u otras formas cívicas.

Como consecuencia de todo esto la educación será una iniciación a la vida griega. Pero junto a esa manifestación general, existe también una cultura personal, un sentimiento de autoformación de adquirir conocimiento es decir paideia. Así en el discurso de Isócrates a Nicocles (Jaeger, 1988, 875880 ), dedicado a la educación del príncipe, se presenta la paideia como la areté que es el más alto de los bienes, que debe inspirar a todo gobernante. Es el poder de sabiduría y del conocimiento a través del logos, que es el creador de toda cultura: "Es el logos el que nos ha permitido realizar casi todo lo que hemos creado en materia de civilización. Él es el que ha estatuido normas sobre lo justo y lo injusto, lo bello y lo feo [...] gracias a él educamos a los necios y conocemos a los inteligentes [...] nada de cuanto en el mundo acontece de un modo racional acontece sin logos [...] por eso debemos considerar a los que desprecian la educación y la cultura tan odiosos como los que se rebelan contra los dioses" (Nic., 5. 2a mitad, 9). En esta exposición de su pensamiento Isócrates presenta los valores de la cultura como fundamentales para la educación del príncipe quien debe buscar la felicidad del pueblo, pero ello también es válido para los hombres en general.

Se ensalza la cultura de los ciudadanos, cuestión ésta que veremos representar en los epitafios de los difuntos, y ello no será privativo de los hombres de letras o ilustrados, sino que cualquier ciudadano gustará de ser recordado como iniciado en la cultura o ciencia de las Musas. La felicidad se asocia a la forma de vida del hombre ilustrado o del artista, llegando casi a constituir una religión, un preludio de lo que puede ser la vida tras la muerte en los Campos Elíseos. Esta concepción de la cultura mirará hacia la transmisión de un patrimonio literario representado por las grandes obras maestras, que conforman una escala de valores. Hay un reconocimiento a determinados maestros que son reconocidos, admirados e imitados. Esa imitación no es pasiva, sino que partiendo del maestro reconocido, de su auctoritas, puede superarse. Sin embargo, el resultado fue la canonización de una serie de personajes, que pasaron a ser considerados clásicos. La educación que se imparte confecciona un canon (Bloom, 2001) de grandes hombres, entre legisladores, pintores, escultores, arquitectos o literatos, que se codifica y aparece en listados de diez, a partir del siglo II a. C. en el círculo universitario de Pérgamo. A su vez tras la selección de autores, se establecía un expurgo de su obra. Es esa la razón por la que se han perdido muchas obras de autores antiguos. De este modo de las cuarenta o cuarenta y cuatro comedias que Aristófanes escribió sólo nos han quedado once que Símaco el gramático editó en el año 100 para uso escolar. Pero el canon, no sólo comprendía literatos o filósofos, también pintores como Apeles o escultores, como Praxíteles o arquitectos como Fidias. Se asiste a una continua referencia al pasado, como "recuperación" en un intento de justificar o dar sentido al presente (Plácido Suárez, 1992, 11-25) que queda vinculado a un pasado prestigioso. Ello supone un interés por los hechos históricos y por las obras o monumentos que el pasado les ha legado. El caso de Atenas es especialmente paradigmático en este sentido. Es una ciudad que se considera heredera de los héroes, anclada en su pasado lo que le dificulta la creación de su propia imagen democrática. En el siglo IV a.C. la ciudad se encuentra de lleno inmersa en su experiencia democrática, pero sin embargo el peso del arcaísmo, le hace imposible generar unos arquetipos basados en el demos y no en el ideal aristocrático. La educación gira en torno a las fiestas de la ciudad, las procesiones y los sacrificios a los dioses: valores cívicos y religiosos, que servían para que los futuros ciudadanos asumieran las costumbres y ritos de sus antepasados. Ello otorgaba a los templos, estatuas cultuales y espacios cívicos: vía de las procesiones, un valor especial, que suponía asumir el deber de conservación, piadoso y civil, según que casos. Junto a este patrimonio material, la educación transmitía un patrimonio literario de grandes obras maestras, que son reconocidas y admiradas, 
en cuya cúspide se halla Homero. Las historias del pasado y de la mitología son convertidas a través de los frontones en "biblias de piedra" que sirven para ilustrar al ciudadano y son a la vez expresión artística de los mitos y acontecimientos. Ellas servirán para "educar" al pueblo en sus creencias y valores, y se convierten en patrimonio común.

3. El INTERÉS POR la Historia y la ARQUEOlogía. Los griegos no se sentían ligados a una cultura anterior y no tenían conciencia de posibles lazos con otras culturas. Maravall $(1989,116)$ se refiere a ello como "el adanismo de los griegos", actúan y sienten como si fuesen los primeros. Su historiografía y poemas están llenos de referencias a otros pueblos pero no conciben recibir nada de ellos, están interesados en eso pueblos de una manera "etnográfica”. De este modo Platón (Thim, 22) nos refiere como Solón, fue acompañado por un sabio en Egipto quién le dice que los griegos son jóvenes, y no poseen ni doctrinas ni ciencias antiguas. Los antiguos a los que los griegos se refieren en numerosas ocasiones, son también griegos, y no se hallan separados del presente, viven en un espacio casi atemporal. Así en los diálogos platónicos Sócrates se refiere a Homero, Píndaro y otros, como gentes pertenecientes a su propio grupo. En el desarrollo de las facultades humanas, Platón (Leyes, III, 677 a 678) aunque parte de un reconocimiento del esfuerzo humano, las mantiene en el terreno del mito, y por tanto, fuera de la Historia (Maravall, 1989, 117). Sin embargo será Platón (Hippias, 285 d) el primero que use el término "arcaiologia" entendida como relato que tiene un origen distinto al histórico.

En Aristóteles vemos algunas referencias a los tiempos antiguos, en su obra la Política y un cierto interés por el pasado en obras como La Constitución de Atenas, donde distingue los antiguos de los presentes y en él se observa un planteamiento más cercano a un concepto de historia. Sabe distinguir los conceptos de democracia y tiranía entre los antiguos y en su tiempo; cambios qué ve justificado por la evolución económica de las ciudades (Maravall, 1989, 117). Previene sobre estas transformaciones y aboga por la defensa de la ley vieja, fortalecida por el uso. A las novedades Aristóteles prefiere la noble$\mathrm{za}$, la riqueza y las virtudes antiguas (Política, 48, $51,183$ y 215$)$.

No obstante, también desde muy temprano los restos e imágenes del pasado servirán, excepcional- mente, a algunos historiadores griegos -aquellos que se enfrentan racionalmente al pasado superando el esquema mítico y legendario- para comprobar o refutar las leyendas o tradiciones. Tal es el caso de Heródoto (Hist., I, 24), cuando se apoya en la existencia en el Ténaro de Corinto de un exvoto de Arión en bronce, en el que figuraba un hombre sobre un delfín, para analizar la verosimilitud de la leyenda que contaban los corintios, relativa al salvamento milagroso del poeta Arión, que obligado a arrojarse al mar por los marineros que lo transportaban, con el deseo de asesinarlo y robarle, fue conducido a lomos de un delfín hasta Corinto o también cuando rechaza la fantástica narración que contaban los sacerdotes de Sais en Egipto, acerca de las estatuas que en el templo existían y que ellos hacían remontar nada menos que al reinado de Mikerinos. Estas estatuas estaban formadas por una de una vaca y otras varias femeninas. La leyenda decía que la vaca era en realidad la tumba de la hija de Mikerinos, que había sido forzada por su propio padre y terminó ahorcándose, y las de las mujeres pertenecían a las sirvientas que habían entregado la hija al padre a las que la madre de la princesa ordenó cortar las manos. En los tiempos de Heródoto, los sacerdotes aseguraban que por esa razón las estatuas carecían de manos. Heródoto (Hist., II, 129-131) rechaza la versión de los sacerdotes: "vimos que estas estatuas han perdido las manos por acción de los años, pues todavía en mi tiempo se las veía caídas a sus pies".

Pausanias, por su parte, describe muchos lugares que pueden considerarse ruinas arqueológicas como Tirinto y sus murallas ciclópeas (Hell. Per., II, 25), la Acrópolis de Tebas (Hell. Per. II, 16, 5), Delos y Micenas (Hell. Per. VIII, 33,2). También Tucídides, cuya obra recibe el nombre de archaiologuía, hace una deducción histórica de un dato arqueológico, él sostiene que los fenicios y los carios eran piratas que vivían en tiempos remotos en las islas del Mar Egeo: "Y aquí tenéis la prueba. Cuando, durante esta guerra, los atenienses purificaron Delos y quitaron todas las tumbas de la isla, más de la mitad de los despojos resultaron ser carios, reconocibles por la armadura enterrada con ellos y por el sistema con el cual aún hoy entierran".

A Heródoto (Waters, 1966, 17-22), a pesar de lo dicho anteriormente sobre algunas conjeturas arqueológicas se le viene considerando tradicionalmente como el "padre de la Historia" aunque su principal actitud es su fascinación por la antropolo- 
gía y por la etnología lo que nos ha permitido contar con una información detallada de las costumbres, creencias religiosas y ritos fúnebres de muchos pueblos e importantes datos sobre templos-tumbas de los lidios o de las pirámides. Pero Heródoto no describe los restos materiales del pasado, salvo algunas excepciones a las que ya nos hemos referido. Le interesa la historia natural, las costumbres de las sociedades vivas. Tal vez en esto jugará un papel importante las colonizaciones y el comercio que pusieron en contacto a los griegos con el mundo exterior. Existía una necesidad de saber cómo eran esos pueblos.

Es probable que Heródoto comunicase su obra a través de narraciones públicas, al igual que los rapsodas recitaban a Homero. Es importante recordar que en aquellos tiempos pocas personas tenían la oportunidad y no todas la capacidad de leer un libro, es decir un rollo de papiro. Por consiguiente era a través de "conferencias" el modo en que nuestro historiador publicitaba sus trabajos. La forma más normal de publicación, en el sentido de hacerlo público, era la lectura en voz alta o recitación en público. El verso había sido el sistema habitual para la transmisión oral, sin embargo la prosa se fue abriendo camino por la necesidad de copiar en piedra, madera o papiro, las decisiones, leyes o tratados internacionales. De ahí la importancia de incluir en su obra cuentos, anécdotas y otros datos que sirvieran para atraer la atención de su audiencia. Cuantas más situaciones fantásticas o fuera de lo común se narrasen más atención se concitaba. Pero Heródoto utilizó la prosa no la poesía. Y su nuevo método: la exposición de la indagación en materia de historia de hechos que habían sucedido. Su Historia se sitúa entre la ficción narrativa o leyenda de los poemas homéricos y las producciones no poéticas de sus sucesores. Su intención al escribir su Historia de las guerras persas, conservar el renombre o proezas notables tanto de los griegos como de los no griegos y de explicar la causa de la lucha entre ellos. Lo verdaderamente revolucionario de su obra fue el rechazo a cualquier implicación divina entre las causas, buscándolas siempre en razones humanas: "Heródoto de Halicarnaso expone aquí su indagación, con el propósito tanto de impedir que la historia de la humanidad se borre con el paso del tiempo, como de conservar la fama de obras extraordinarias y maravillosas de parte de helenos y bárbaros; y en particular, la causa de la guerra entre ellos”.
Cuando Heródoto (Waters, 1966, 31-35) se dispuso a la enorme tarea de escribir sobre acontecimientos que habían sucedido cuarenta años antes -las guerras médicas- sus fuentes eran orales y sus testigos -los más jóvenes-, estaban ya influidos por los rasgos de epopeya griega y mítica de los sucesos. La única forma que tuvo de prepararse fue por medio de los viajes, de la visita a los lugares donde se sucedieron los acontecimientos. Una autopsia, una investigación visual personal, interrogando a testigos, copiando inscripciones, recogiendo tradiciones orales sobre la campaña. De sus narraciones se desprende un buen conocimiento de lugares y templos sagrados, como Dodona (2.52), Tebas (5.59), las Termópilas (7.198 ss), Tempe y Olimpia (7.129) y sobre todo los grandes santuarios de Delfos, donde estaba seguro de encontrar una buena fuente de información a través de las muchas inscripciones y dedicatorias, así como por el carácter panhelénico del santuario que congregaba griegos de todas partes que eran una importante fuente, sin olvidar la importancia del Oráculo.

Visitó la isla de Samos, los estrechos del Mármara y la Tracia. Y sin duda estuvo en Egipto donde pasó un tiempo considerable. Sabemos que visitó Menfis, Tebas y Heliópolis. Sin embargo, no es probable que viajara más hacia Oriente. Aunque sí parece cierto su viaje a Tiro y Babilonia. Los griegos no entendían ni se les ocurría necesario el aprendizaje de idiomas extranjeros y mucho menos entretenerse en traducir las copiosas pruebas escritas orientales. Heródoto fue recogiendo datos, de aquí para allá, pero icómo lo registraba? Los griegos desconocían una taquigrafía, salvo que Heródoto tuviera un sistema que no nos ha llegado, algo parecido al Notae Tironianae que mucho más tarde inventó Tirón el secretario de Cicerón. Todos estos registros serían voluminosos. No sabemos si en rollos de papiros tremendamente incómodos. En contrapartida tendría que haberlo retenido todo en su cabeza, absolutamente imposible. Tuvo a su alcance una gran cantidad de materiales: catálogos de oráculos, cuentos o logoi y no tuvo a su alcance una narración continua sino una gran cantidad de informes orales. Nunca sabremos cómo logró organizar y sintetizar tanta documentación con los medios técnicos de la época.

Por su parte, Tucídides (Jaeger, 1988, 347-369) es el creador de la historia política. El momento histórico clave que le tocó vivir en una Atenas, que había alcanzado cotas enormes de participación 
ciudadana y de madurez política, y que se transforma en un "imperio" ático, lleva consigo un interés por el conocimiento histórico como consecuencia del desarrollo de su pensamiento político. De este modo el pensamiento político se hace histórico. Y aquí aparece Tucídides como creador de la historia política, pero ¿Qué pasado despierta interés en él? En principio debemos decir que su interés es el pasado inmediato: la guerra del Peloponeso, una historia que pertenece a su propio presente. Almirante de la flota, la guerra lo hizo historiador. Pero sus incursiones en el pasado son incidentales o traídas como argumento que resalta la importancia del presente. Su primer libro recibe el nombre de arqueología que parece llevarnos a un importante interés por el pasado. Pero ello no es así. El pasado de los griegos no le interesa, porque considera que fueron tiempos incapaces de generar una estructura estatal moderna. Eran tiempos inseguros que impedían tener la quietud necesaria para establecer una organización sólida. Mira hacia el pasado con ojos de un político contemporáneo. Sin embargo, presenta importantes novedades, así Homero es visto descargado de prejuicios. De sus textos saca conclusiones históricas, interpretando la obra homérica como fuente directa. Considera a Agamenón como el primer gran poder helénico, sostenido por una gran armada. Como marino, Tucídides da una gran importancia al catálogo de navíos de la Ilíada, y aún con cierta reserva saca de esas fuentes la magnitud del contingente militar griego. Aunque resalta su carácter primitivo, considera la guerra de Troya como la primera empresa naval de la historia de Grecia. De este modo hace toda una evolución política basada precisamente en la evolución del poderío naval. Lo que le lleva a analizar las guerras contra los persas y la liga ática. Esa es la importancia que tiene para él la prehistoria. Parte de la concepción objetiva de la historia y de los acontecimientos históricos, los cuales de acuerdo con la naturaleza humana suelen repetirse en el futuro del mismo modo o de un modo análogo. De ahí la importancia de estudiar de forma objetiva el pasado. Busca leyes universales y permanentes en la Historia. Todo esto es muy importante para la cultura política, pues solo siendo previsores y sujetando la acción política a la planificación estratégica es posible prevenir el porvenir. Esta acción previsora la vemos en la frase de Aristóteles (EN, 1140, b): "Pericles y los que son como él son prudentes porque saben ver lo que es bueno para ellos y para los demás y pensamos que esta cualidad es propia de los administradores y de los políticos”.

Sin embargo, salvo esas excepciones, los historiadores antiguos no se apoyarán en los testimonios materiales para interpretar el pasado. Es decir la arqueología como ciencia que descansa precisamente en esos materiales no floreció en la antigüedad.

En este sentido, Daniel (1967, 34), afirma que aunque hay casos de coleccionismo en la Antigüedad a los que en capítulo aparte nos referimos, la arqueología tal y como la entendemos ahora no existe en el mundo antiguo, ni tan siquiera como interés por el pasado. Habrá que esperar a la ciencia anticuaria del Humanismo, verdadero precedente de la arqueología clásica. Ya nos hemos referido a que algunos griegos como Heródoto hicieron observaciones que podríamos considerar hoy dentro de la ciencia de la etnología. En algunos de sus viajes tomaron contacto, lógicamente, con gentes que se hallaban en un estadio "superior del salvajismo o inferior de barbarie", siguiendo la definición de Morgan (1971, 83). Pero en esos contactos no realizan una actividad científica que pudiera considerarse cercana a una investigación arqueológica, todo lo más usan unas descripciones de costumbres. Esa es la opinión de G. Daniel, apoyándose en Phillips $(1964,171)$, quien afirmaba que ni los griegos, ni los europeos de los siglos XVIII y XIX conocieron la arqueología. Afirmación que nos parece excesiva pues no tiene en cuenta el trabajo de numerosos personajes desde el humanismo hasta la primera mitad del siglo XIX. En opinión de Philips sí se realizaron descubrimientos pero fueron puramente casuales y nunca fueron el resultado de una búsqueda premeditada de conocimiento sobre las épocas anteriores. Ni mucho menos se llevó a cabo una comparación y clasificación, y no pudo, pues, obtenerse una cronología mediante ellos.

Por su parte, los romanos si poseen un concepto claro de cultura heredada. En primer lugar está su referencia a los mayores, a los ancianos, a los veteres. Cicerón (De Republica, I, 21) considera que hay un legado transmitido por maiores nostri, y una deuda con una cultura que le ha precedido. Según Maravall $(1989,120)$ Cicerón es el primer gran hombre culto para el que los antiguos ejercen su función de maestros. Los antiguos para él son los griegos, "nosotros hemos sido enseñados por los griegos” (Tusculunae, II, XI, 27). Pero Cicerón no pretende imitar a los griegos, ni repetirlos de forma mimética. Él desea aprender de ellos, y superarlos 
desde su estilo romano. Ello le lleva a un patriotismo, que le hace mostrar un interés por el pasado de Roma y su historia. El resultado será, como advierte Maravall $(1989,121)$, que al valorar tan altamente un pretérito, el del propio pueblo, se valora a éste en su presente como resultado de tan alta historia.

En el caso de Virgilio, vemos también la tendencia a ennoblecer los orígenes de un pueblo presente, presentando una nueva edad. Motivo éste que veremos convertido en algo común en el Renacimiento. Virgilio (Egloga, IV, 7) anunciará el renacer de la edad de oro, la de la felicidad, que cantaba Hesíodo, del reino de Saturno: una nueva y admirable generación que el cielo envía: magnus ab integro saeculorum nascitur ordo. También Séneca y Ovidio proponen la renovación de la edad de oro, que tanto influirá en el Humanismo.

Horacio en su epístola Ad Pisones hace un elogio de los griegos y su magisterio, y recoge en un verso su clara conciencia de la mutación de los tiempos: multa renascetur quae iam cedere (De arte poetica, 70), y su convicción que de las cosas pasadas pueden salir otras nuevas.

Tito Livio es quizás el autor más interesado por el pasado de los romanos. Considera que hay que empezar a estudiar la Historia de Roma desde sus orígenes, desde esa primera edad primitiva, donde supone él que la sociedad aún no está corrompida, y llega a ese camino de investigación del pasado preocupado por la sociedad romana de su tiempo, quiere rastrear la vida de los hombres que lograron con su ejemplo y costumbres sentar las bases de la grandeza espiritual de Roma.

También, y como contrapunto, surgirá la sátira. Con ella se medirán los vicios que corrompen la vida de Roma, y la indignación hacia ellos, y lo hacen desde una actitud realista sin interesarles el pasado para nada, ni mucho menos los temas considerados nobles vinculados a ese pasado o a la moraleja de la mitología. Juvenal y Marcial, detestarán a los que admiran las vetusteces, las reliquias, las antigüedades; no desean escribir de centauros ni gorgonas, ni de leyendas mitológicas, solo las cosas que ocurren diariamente, la realidad cruda y divertida de la vida.

Quintiliano (Institutiones oratoriae, II, VI) también mira hacia el pasado, cuando propone que hay que imitar a los antiguos, averiguando lo que en uno y otros está mal o bien, es decir una imitatio de los antiguos sin sumisión al pasado. Llama también la atención sobre aquellos que admiran de- masiado a la antigüedad, que les hace caer en estilos rudos y arcaicos, frente a los tempora nostra.

Es esta época, siglo I, un momento muy polémico en la cultura de Roma, la disputa entre los antiguos y los modernos alcanza una cota importante, como vemos en Tácito, y en su obra De Oratoribus, en la que él mismo se decanta por los primeros, aunque pone en boca del defensor de la modernidad argumentos muy contundentes. En la discusión se advierte una preocupación por la educación y el valor de los autores de los libros antiguos: in antiquariorum bibliothecis. También se observa un temor ante la posible pérdida de las costumbres antiguas, oblivione moris antiqui.

Varrón, por su parte, elabora el concepto de antiquitates, un equivalente de la arcailogia de Platón, que responde al intento de convalidar o de exaltar el presente a través del reconocimiento de la riqueza y del peso de la tradición sobre el que el presente se funda y por el cual se legitima (Cantino, 1984, 175). Su obra Antiquitates rerum humanarum et divinarum, reúne una gran cantidad de información sobre usos, costumbres, lengua y literatura, que parten desde un análisis del pasado. Para Varrón, antiquus es aquello que precede en el tiempo y precisamente por ello, por su antigüedad, es motivo de veneración y respeto, y se haya ligado al presente a través de un delicado proceso de transmisión que se percibe como un continuum. En esta concepción de lo antiguo, los objetos adquieren un valor artístico o religioso, y también son testigos de hechos ligados a las glorias del pasado o a simples acontecimientos históricos, que están íntimamente relacionados con el imaginario del pueblo que lo interpreta. Con Varrón comienza a dibujarse el concepto de monumento sagrado, cosas consagradas a los dioses, templos o tumbas y el histórico, en referencia a aquellos edificios u obras que están cargados de una clara intención de glorificar hechos o acontecimientos ligados a la vida de los romanos y también a exaltar la figura de aquellos que con sus hazañas lo han hecho posible.

Todo este conjunto de creencias e inquietudes producen un interés de los romanos por la Antigüedad, siendo uno de sus problemas el definir los límites temporales de aquélla. Volviendo de nuevo a la citada obra de Tácito, el personaje que hace una defensa de los "nuevo" como antítesis de lo "antiguo", cuestión ésta presente a todo lo largo de la obra, estima que sólo pueden ser antiguos aquéllos que están alejados del presente más de mil años. Lo 
que situaría a Alejandro entre los "modernos" contemporáneos de Tácito. Sólo serían "antiguos” los héroes de Troya. Grecia será la nutriente de los romanos, pero los griegos serán considerados hombres modernos de los que apenas les separan unas pocas generaciones. Es un mundo en el que la historia parece correr con una lentitud que no alcanzamos a veces a comprender. Por eso las comparaciones con personajes alejados de sus contemporáneos como si convivieran en un presente eterno, se nos antojan curiosas y difíciles de entender. Tal es el caso de aquellos cronistas, como Eutropio (Brev., VIII, 5.3) que recogen la salutación de los emperadores por el Senado, cuando les decían más de 300 años después: Felicior si Augusto et Traiano melior (iQue seas más feliz que Augusto y más prudente que Trajano!), como si para ellos aquellos césares fuesen sus contemporáneos. Lógicamente unos sentimientos como estos también producirían una admiración por las obras que les recordaban a esos personajes de la historia de Roma, o que habían sido realizados por ellos: esos monumentos que recordaban la memoria de los hechos y de la vida de Roma o de Grecia (Verdugo, 2015) y que por tanto cuidaban y protegían, admiración que veremos en escritores y viajeros como Pausanias. Junto a estas obras o creaciones humanas ligadas a la historia y a los hechos de los grandes personajes, aparecen otras realizadas por el hombre que causan admiración por su escala o importancia, que se inscriben bajo la rúbrica de lo maravilloso.

\section{El Mito de AtLÁNTIDA.}

El mito de la Atlántida es una de las grandes creaciones del mundo antiguo respecto a un acontecimiento que se sitúa en el pasado. El mito se debe a Platón quién lo recoge en el prólogo del Timeo y en el Critias y ha ejercido una fascinación desde la antigüedad hasta nuestros días. La mayoría de los intérpretes de la narración de Platón han dado por buena la tesis de que la Atlántida, o bien existió, o es el eco de un acontecimiento histórico que Platón recogió como leyenda, transformándola en mito. Los intérpretes más comunes de la tradición del hecho histórico centraban su explicación en la influencia cretense. En la Atlántida, están presentes toros y conjuntos monumentales que podrían fácilmente conectarse con Creta, pero ante ello surge la duda que se plantea Vidal-Naquet (2006, 15-19): ¿Cómo es posible que Platón hablara de una civilización que desconocía por completo y qué había desaparecido un milenio antes de su época? La respuesta está en que, a juicio del mencionado autor, Platón no pretende de ningún modo recoger un hecho histórico ni parte de la base de la existencia real de la Atlántida, sino que al contrario todo el mito no es sino una crítica a la Atenas de Pericles, como veremos más adelante.

El tema de la Atlántida ha estado presente en el imaginario occidental desde Platón a nuestros días, y ha supuesto un referente mítico para los europeos. Numerosas teorías han intentado situar la Atlántida en el marco de un acontecimiento histórico, así Eberhard Zangger (1992) plantea la hipótesis de la Atlántida troyana; o la teoría de Marinatos (1969), que la sitúa en Thera, cuya destrucción fue un suceso que además supuso un punto de inflexión en la civilización antigua precipitando el hundimiento del mundo creto-micenico. Esta explosión de Santorini (Thera) es a juicio de Marinatos la inspiración de la leyenda tras un viaje de Platón a Egipto. Volviendo a la teoría expresada por Vidal-Nauquet (2006, 25-46), la Atlántida parece no responder a un acontecimiento histórico o a un accidente geográfico. Los textos de Platón redactados en torno al 355 a. C., se sitúan históricamente en el momento del fracaso de la segunda Confederación ateniense cuando Atenas renuncia al imperialismo marítimo que había permitido su poder hegemónico desde el final de las guerras médicas. Los personajes, Timeo y Critias, el primero un pitagórico cuya existencia histórica puede tener cierta verosimilitud es un ciudadano de Lócride en Italia, que ha ocupado importantes cargos y ha recibido importantes honores en su ciudad. El segundo, Critias, es el que nos da noticias de la Atlántida que ha recibido a su vez de su abuelo Critias el Viejo quién le contó que Solón había escuchado esta historia de los sacerdotes de Net, la Atenea egipcia. El texto como todo el mundo sabe se interrumpe. Ello ha suscitado numerosas discusiones acerca de su continuidad, sin que nadie repare en que tal vez Platón nunca quiso terminarlo, o dicho de otra manera que el texto se interrumpa voluntariamente en ese punto.

Esta tesis de Vidal-Nauquet, puede verse, de algún modo, avalada por la opinión de Onians (1996, 9-26) para quien el relato de Platón recoge la distinción entre Atenas, ejemplo de la cultura griega preclásica y la Atlántida, un ejemplo de cultura bárbara, materializando la conciencia que Platón posee respecto a la subordinación de la práctica artística a su estructura política y a su organización econó- 
mica. La Atenas, que describe Critias, dice Onians, corresponde en sus aspectos esenciales de organización a la ciudad-estado anterior al siglo VI a. C., y su arte está al servicio de la religión. Mientras tanto, continúa el referido autor, la Atlántida guarda gran semejanza con las civilizaciones orientales, o con las ricas ciudades jónicas en especial con la Atenas del siglo $\mathrm{V}$ a. C., modelo que luego desarrollarán hasta el máximo exponente las monarquías helenísticas y Roma. De este modo, Atenas es un ejemplo de ciudad austera cuyos ciudadanos siguen el ritmo de las estaciones, mientras que los habitantes de la Atlántida construyen termas y prefieren los espectáculos deportivos del hipódromo a su propia actividad física en los gimnasios. ¿Es la Atlántida un estado bárbaro? Esa parece ser la opinión de Onians, que subraya como los rasgos de la Atlántida se inspiran en civilizaciones bárbaras. Pero también subyace con cierta claridad una crítica a la propia Atenas en la semejanza entre la estatua de Poseidón atlante y la de Atenea del Partenón entendida por Platón como un derroche asiático. Lo más llamativo de la obra sería, sin embargo, su carácter profético pues más que presentarnos civilizaciones previas como aparenta parece que nos está anunciando los mundos helenísticos o romanos, es decir el lujo de las monarquías helenísticas que aparecerán en un momento posterior o en las formas y estilos de vida de los romanos altoimperiales. Todo ello hace de esta visión de la Atlántida que Onians y Vidal-Nauquet nos transmiten la constatación de una llamada de atención que Platón hace sobre la evolución que podía sufrir el campo de la cultura y la política en la sociedad antigua de su tiempo. La civilización helenística y romana, que Platón nos anticipa.

\section{SEPTEM ORBIS SPECTACULIS.}

La idea de las maravillas en la Antigüedad, es un elemento que constituye, en opinión de Ramírez Domínguez $(1983,26)$ la imagen mental de una ciudad-espectáculo que es el compendio simbólico del Imperio de Alejandro. El primer tratadista que hace mención a ellas es Filón de Bizancio, hacia el 150 a.C., que menciona los jardines de Babilonia, las pirámides, el coloso de Rodas, el mausoleo de Halicarnaso, el templo de Artemisa de Éfeso y el de Zeus en Olimpia (Figura 1). En dicha lista, no figura el faro de Alejandría, cuestión ésta que llamó la atención a Ashley (1970, 20-21), quien considera que tal vez la lista de Filón era tan sólo una copia de una compilación anterior, escrita unos dos años antes, cuando Alejandro está fundando Alejandría y quería devolver su esplendor a Babilonia y convertirla en la capital oriental de su imperio.

De este modo, las "maravillas" serían el elemento de afirmación de los vastos territorios conquistados e imagen ideal del Imperio marcando su contorno (Ramírez Domínguez, 1983, 26). De todo ello se deduce con cierta verosimilitud que el propio Alejandro encargase, tal vez al historiador, ingeniero y arquitecto: Aristóbulo, un Libro de las Maravillas, y que en el mismo no apareciese el faro de Alejandría
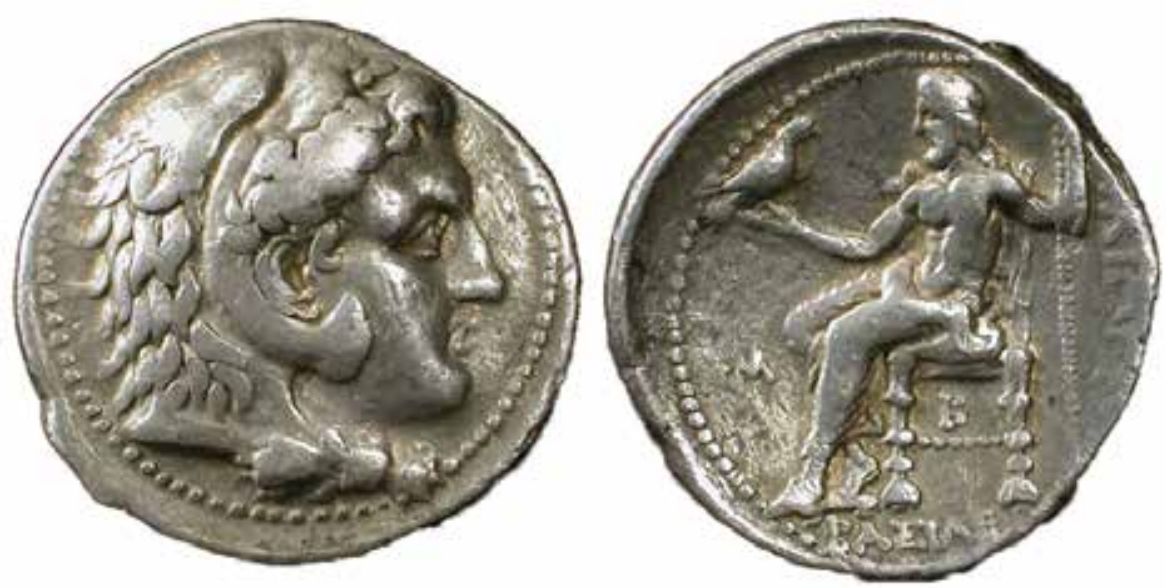

Figura 1. Septem Orbis Spectaculis. Zeus de Olimpia. Moneda de Alejandro el Grande (336- 323 a. C.). Tetradracma de plata. Cabeza de Hércules y Zeus en su trono de Olimpia. La estatua fue llevada a Constantinopla por Lausus, praepositus sacri cubiculi, en época de Teodosio II (406-450) tras la supresión de los festivales olímpicos en el 394. También sabemos que el templo de Zeus en Olimpia se incendió en el reinado de Teodosio II. En cuanto a la escultura fue destruida por un incendio del palacio de Lausus en el 475, con toda su colección @ Javier Verdugo. 
puesto que aquél fue erigido después de la muerte de Alejandro, acaecida en Babilonia en el 323 a.C. Sin embargo, toda esta teoría elaborada por Ashley, no parece convencer mucho a Ramírez Domínguez $(1983,26)$, quien le "parece demasiado positivista".

En su opinión, las maravillas no tienen por qué ser reales, y pone de ejemplo los jardines colgantes de Babilonia, que habían sido destruidos en el 482 a. C., pero cuya fama se había mantenido en la memoria, a través de descripciones más o menos legendarias. También destaca que alguna de ellas como el Coloso de Rodas sólo permaneció en pie 63 años, pero su fábrica causó una impresión entre los viajeros, que quedó grabada para siempre en el imaginario, y se incorporó de este modo a la lista de obras asombrosas. Lo mismo ocurre con el número siete, cifra mágica con numerosas connotaciones en el mundo antiguo: los siete sabios, los siete planetas, las siete colinas de Roma, las siete plagas sobre Egipto, las siete notas musicales y los siete colores de la gama cromática. Es el número del orden cósmico, del orden de la Creación bíblica, con un sentido de buena suerte y de fortuna. No es extraño, que se elaborase una lista de maravillas: Septem Orbis Spectaculis. Para Ramírez Domínguez $(1983,29)$ la idea pudo nacer en tiempos de Alejandro, pero alcanza su máximo desarrollo y formalización en época helenística y romana, y tendrá repercusiones en la Edad Media y sobre todo en el Renacimiento y en el Barroco.

Para Ramírez Domínguez $(1983,29)$ desde su creación las Maravillas del Mundo, "aparecen como un compendio imaginario de las grandes realizaciones del hombre sobre la tierra", un conjunto de obras emblemáticas perdurables, que serán eternas, incluso más allá de su desaparición física, y que se incorporan al mundo de la utopía. Para los hombres de la Antigüedad "les proporcionan los elementos monumentales básicos de una polis universal, mítica, para ser mirada". Estamos ante los primeros monumentos entendidos como realizaciones asombrosas hechas por el hombre, que se convierten en arquetipos y en símbolos eternos.

Esa "mirada" irá dirigida a las enormes tumbas del desierto: las pirámides y a un mausoleo urbano decorado con magníficas esculturas: Halicarnaso. Las primeras se convertirán en una imagen a imitar, como ocurrirá con la pirámide de Cestio, y el segundo dará su nombre a todo tipo de tumba monumental: mausoleo. La forma más cuidada y perfecta de representar a Dios, será la estatua de Zeus de Olim-

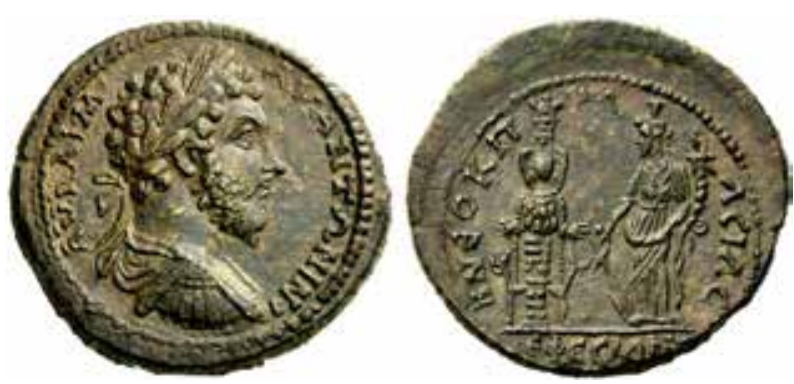

Figura 2. Septem Orbis Spectaculis. Estatua cultual de Artemisa. Moneda de Marco Aurelio (161-180). Artemisa y Tyche. Leyenda, anverso: AY KAI M. AV ANT $\Omega$ NIN. Rev. B NEOKП - P $\Omega$ - ACIAC. EФECI $\Omega N$ ㅇ Javier Verdugo

pia y a la divinidad de lo femenino, la Artemisa de Éfeso (Figura 2), y su santuario, templo paradigmático. Los jardines de Babilonia y el Faro de Alejandría (Figuras 3 y 4), serán ejemplos de lo "lúdico utilitario" (Ramírez Domínguez, 1983, 29) de que lo útil puede y debe ser además bello. Por último el Coloso de Rodas, será un ejemplo de lo espectacular, que tanto influirá en las obras del mundo romano, y que por su semejanza dará nombre al Coliseo de Roma, que como una octava maravilla aún perdura.

6. LOS VIAJEROS Y SUS DESCRIPCIONES. LO MARAVILLOSO Y LO ASOMBROSO.

Los griegos eran un pueblo viajero acostumbrados al comercio marítimo y a llevar a cabo expediciones en las costas que visitaban. Como consecuencia de esa práctica viajera y exploraciones hicieron su aparición los Periplos, descripciones de viajes $\mathrm{y}$ de las tierras. Estas descripciones, responden en parte a un viaje real, pero en su mayoría: "se tratan tan sólo del fruto de la especulación geográfica o de pura fantasía" (García Moreno et al., 1996, 7). No es fácil por tanto deslindar lo real de lo imaginado. $\mathrm{Al}$ parecer, muchos de ellos nunca estuvieron en los lugares que describen, como Ctesias de Cnido, que no estuvo en la India o Agatárquides, que no visitó las costas del mar Rojo o del Índico, o Dioniso el Periegeta, que narra un viaje imaginario aéreo. Igualmente Marciano de Heraclea sólo se apoya en lecturas y experiencias ajenas. Sí, por el contrario, es más real el recorrido de Arriano por las costas del mar Negro; el de los comerciantes que describen los periplos del mar Eritreo o el masaliota, recogido por Rufo Festo Avieno, en su Ora Maritima. También está el Periplo de Hanon, considerado, por algunos, pura invención literaria, y por otros como 
un viaje auténtico realizado por los cartagineses en el siglo V a.C.

Parece que con el transcurso del tiempo los periplos, en su origen manuales de navegación, se fueron convirtiendo en un género literario más (García Moreno et al., 1996, 39), por influencia de un gusto por lo exótico y rarezas del mundo exterior, como consecuencia del interés etnográfico jonio del siglo VI a.C., quiénes pensaban que en los confines del mundo era posible que sucedieran cosas fantásticas, como afirma Heródoto (Hist. III, 116,3). Hace su aparición lo maravilloso, la búsqueda de cosas extraordinarias género que perdurará en la cultura occidental hasta hoy. También lo maravilloso rayaba en lo extravagante, como ocurrió con Ctesias de Cnido, que apareció ante sus contemporáneos como un autor nada fiable (García Moreno et al., 1996, 11). Nos interesa saber si en estos periplos, se recogen noticias acerca de monumentos intencionados, que pudieran llamar la atención, tanto al escritor como al lector. Cuestión ésta, que nos permitiría aventurar si en estas fuentes hay indicios de un cierto interés por el pasado de los pueblos y sobre sus monumentos singulares.

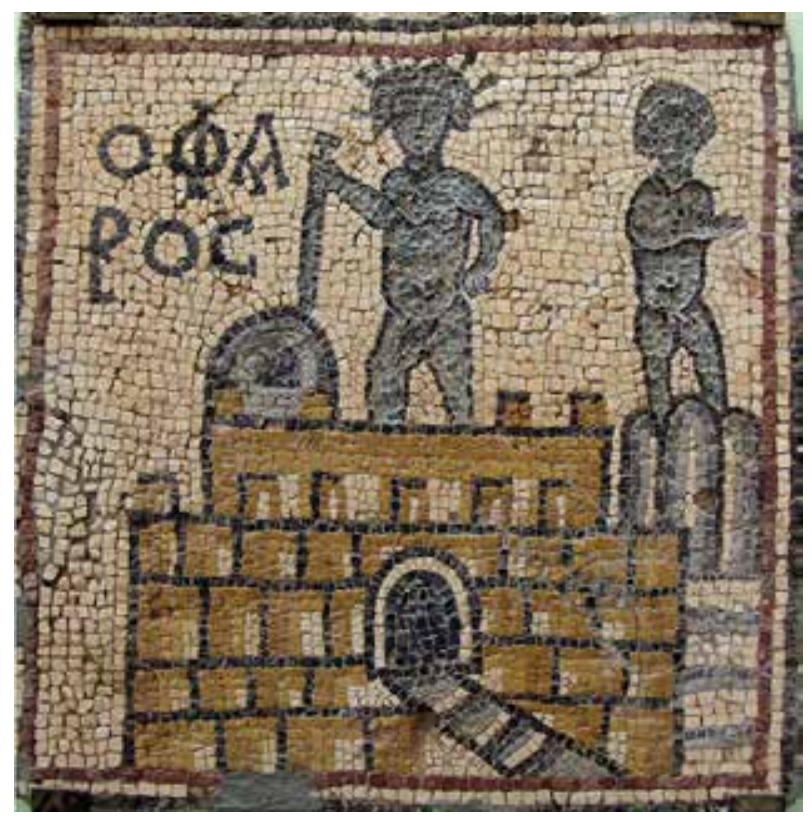

Figura.3. Septem Orbis Spectaculis. Faro de Alejandría. Construido por Sóstrato de Cnido por encargo de Ptolomeo I, entre el 285-247 a.C. Fue destruido por un terremoto en el siglo XIV. Se tienen algunas imágenes en mosaicos como este de Qasr Libya, antigua Olbia Theodorias. En él parece apreciarse en lo alto del faro una escultura de Helios (? Qasr Libya Museum.
Nada de ello se encuentra en el periplo de Ctesias de Cnido sobre la India, y escasas notas en el del Pseudo Escílax. Donde hallamos una referencia al sepulcro de Elpénor, compañero de Odiseo, muerto accidentalmente en el palacio de Circe, y que el autor sitúa, sin más comentarios "entre los latinos", probablemente cerca del promontorio del Circeo, donde se pensaba que había habitado la maga (Ctesias, 46.8).También menciona un santuario a Diomedes, héroe griego de la costa adriática, entre los Umbros (Ctesias, 46,16); uno a Poseidón entre los lacedemonios (Ctesias, 61,46) ${ }^{1}$; otro a Demeter en Eleusis (Ctesias, 64,57) y el de Poseidón en cabo Sunión (Ctesias, 64,57). Sorprende, sin embargo, la lacónica referencia a la isla cicládica de Ios, donde sitúa nada menos que la tumba de Homero.

Sentado lo anterior, vemos cómo la historia griega nos dice que Solón visitó los santuarios del Valle del Nilo y que los sacerdotes lo recibieron orgullosos de su pasado, pues tal era el sentimiento que éstos tenían hacia sus tradiciones y monumentos, incluso dicen que los egipcios consideraban a los griegos como "inmaduros". Pero el viaje también es considerado por algunos filósofos como algo que debe estar restringido. Tal es el caso de Platón (Leyes, 967 A.s) que concibe su polis ideal como una ciudad autárquica que debe prevenirse de toda influencia fortuita del exterior. Esta prevención de Platón es reflejo de lo vulnerable que se sentían algunos griegos a la influencia de los bárbaros y de Oriente. En su Paideia, Platón sólo concibe que los viajes se autoricen a los embajadores y a los theoroi. ¿Quiénes son estos últimos? Jaeger (1988, 1072-1074) nos informa al respecto. Según el autor de la Paideia serían hombres de ciencia, testigos de la cultura y de las leyes de otros hombres, que debían dedicarse al estudio de los países y sociedades extranjeras. Su misión sería establecer relación con personalidades descollantes del país que visitasen, "hombre divinos". Platón de este modo está reconociendo la existencia de los viajeros, y expresa su deseo de que se reduzcan a unos pocos, seleccionados por la polis. El mismo Platón había estado ausente mucho tiempo de Atenas, y a ese experiencia personal debe responder su modelo de viajeros. Los griegos siempre habían realizado viajes no sólo por razones comerciales sino culturales. Es esta una característica que sólo se da entre los griegos y después también entre los greco-romanos. Es pues un fenómeno específicamente griego.

1 Entre el puerto de Aquiles y el de Psamantone. 
Ya hemos referido los viajes de Solón a Egipto y Asia, al que también habrían sin duda precedido otros. Y al que sucede Hecateo, Heródoto, Eudoxo y el mismo Platón como ya hemos dicho. En la época de Platón estos viajes con fines culturales eran frecuentes, y tenemos muchos testimonios como el de Eneas Táctico (x, 10) autor de materias militares que distingue entre viajeros de la cultura (cata paideusin) o de los negocios (cat allhn tina Creian). Isócrates (Antid., 224) les llama "estudiosos" que vienen de fuera y el Seudo Hipócrates (Demon.19) menciona los largos viajes que tenían que emprender los "estudiosos" para escuchar a maestros prestigiosos. Finalmente Platón (Leyes, 952 C-D) les confiere una importante misión a los "viajeros estudiosos" en su polis ideal. Deben informar al consejo de la paideia de todo lo observado y cuidándose mucho de evitar influencias o sugestiones perjudiciales para los ciudadanos.

La costumbre de viajar y conocer los templos y santuarios famosos se desarrolla sobre todo a partir del helenismo, y de las conquistas de Alejandro y es común a personajes poseedores de las fortunas necesarias como para poder costear dichos viajes. Desde Heródoto a Apuleyo o Pausanias. Heródoto, padre de la historia y de la etnografía, dedicó el libro segundo de sus Historias, que puso bajo el patrocinio de Euterpes, a Egipto. La primera mitad del libro es, en opinión de Le Goff $(1996$ a, 136) un trabajo propio de un etnólogo, cuando describe las costumbres y usos de los egipcios y señala los elementos que los griegos tomaron de ellos. La segunda parte, es la obra de un historiador interesado en la sucesión diacrónica de acontecimientos, siguiendo las dinastías unas tras otras.

En época imperial romana era muy usual visitar Egipto, país que seguía ejerciendo una gran fascinación, y que además había sido enemigo de Roma, y le cabía el honor de albergar la tumba de Alejandro. Estos viajes, puro afán de conocer cosas, se volverán a retomar con las peregrinaciones en la Edad Media, tanto hacia Tierra Santa como a Roma, con una finalidad religiosa, laicizándose de nuevo con el humanismo. De este modo Egipto, que durante la Edad Media quedará reducido a las pirámides, es descrito por algunos peregrinos en su camino hacia los Santos Lugares, aunque de una manera muy sumaria. En el Renacimiento tanto Egipto como Grecia serán unos perfectos desconocidos y sólo se conocerá de ellos los obeliscos y esculturas que los romanos habían transportado desde esas zonas del Mediterráneo.
En su famosa obra Descripción de Grecia (Helládos Periégesis) Pausanias nos dice que es su intención describir pánta tà Helleniká, "toda Grecia" o más concretamente "todos los asuntos griegos", pero de acuerdo con el criterio selectivo "eligiendo lo más digno de mención" (Pausanias, Hell. Per. III 11, 1):" ...yo no iba a mencionar todo punto por punto, sino eligiendo lo más digno de mención, [...]. Pues he querido separar las cosas importantes de las muchas y no dignas de ser narradas que cada pueblo cuenta sobre sí”.

La obra dividida en diez libros describe lugares, monumentos, obras de arte y relata mitos, leyendas, hechos históricos, hechos maravillosos. Herrero $(1994,17)$ siguiendo a Robert (1904, 8-68) distingue dos elementos (Pausanias Hell. Per. I 39, 3): los lógoi y los theorémata. Los primeros son los mitos, las historias y reflexiones. Los segundos son las cosas que pueden verse, las descripciones de los lugares y monumentos. De los primeros Pausanias es un mero trasmisor y de los segundos ejerce de guía y testigo. En cuanto a la descripción de los monumentos llama la atención que todos sean antiguos y "desprecia todo lo que es moderno, de acuerdo con la tendencia de su época hacia lo arcaico" (Herrero, 1994, 22).

Por consiguiente, a mayor antigüedad mayor interés despertará en el viajero. Los tres monumentos que Pausanias trata más detalladamente son el arca de Cípselo en Olimpia, el trono de Apolo de Amiclas y las pinturas de Polignoto en Delfos. Cronológicamente le interesan, sobre todo, las obras de los siglos V-IV a.C. y primera mitad del III. De este modo cuando describe el Ágora de Atenas menciona edificios muy antiguos, aunque sean modestos, y omite el pórtico de Atalo del II d. C., el de Eumenes o el monumento de Agripa. En Olimpia ignora la Exedra de Herodes Ático. No obstante, y a pesar de su predilección por lo arcaico, también hace alguna referencia a lo moderno, como su admiración por Damofonte de Mesenia (II d.C.).

Como conclusión puede afirmarse que los griegos y romanos se preocuparon por su "historia", por su pasado, y aunque no estudiaron los restos materiales del pasado a través de una disciplina arqueológica, es cierto que conocían la historia de sus principales monumentos, que para ellos representaban símbolos religiosos o patrióticos, cargados de una gran intencionalidad.

El propio Tácito hace un enfoque, que hoy diríamos etnográfico, y con una óptica rousseauniana 
(Le Goff, 1996, 136), al oponer la corrupción de la civilización representada por Roma, a la honradez de los "buenos salvajes", que son los bretones o los germanos. Sin embargo, dedica mayormente su atención a la historia de Roma, excluyendo la de los otros pueblos.

\section{EL INTERÉS POR LOS OBJETOS.}

Siguiendo a Wescher (1988, 3-11), en la Antigüedad pueden distinguirse cuatro formas de "interés" por las obras de arte y los monumentos: como botín de guerra, por su valor económico, por sus cualidades artísticas o estéticas y por su carácter de reliquia. El objeto de valor será también utilizado en las relaciones de hospitalidad y dependencia en el llamado "don contra don".

\subsection{COMO BOTÍN DE GUERRA.}

En el mundo antiguo el botín de obras de arte respondía a "razones de carácter religioso", entrañaba apoderarse de las divinidades y someterlas a las propias lo que les confería un valor más allá de la estética y de su valor económico. En la Antigüedad "los dioses son componentes de lo diario" (Harmand 1985, 75), siendo realmente difícil diferenciar lo sagrado de lo profano en el campo de las normas. En el fenómeno guerrero es necesario contar con la garantía de la protección divina y siempre hay una evocación en los textos a las divinidades como cuando Enmerkar de Uruk quiere doblegar a Aratta a su voluntad y pide a su "hermana" la diosa Inanna que le someta aquella ciudad (Harmand 1985, 76). $\mathrm{La}$ acción guerrera puede responder a una incitación divina o a una venganza. El vencedor tomaba el puesto del vencido, adueñándose del mundo figurativo de aquel y su dinastía pasando al servicio de su nuevo señor, que inscribía su propio nombre en los monumentos consagrados por el viejo poder. Numerosas piezas de origen extranjero se han hallado en las capitales de los asirios, los babilonios o los persas. Estos son tanto figurativos, como los relieves de Khorsabad, como literarias, si así consideramos a las tablillas cuneiformes. Sargón, en una inscripción votiva al dios Assur, refiere como trasladó desde Urzanu, ciudad de Urartu, tras una campaña contra su rey, una gran cantidad de oro y piedras preciosas, la estatua del dios Haldia procedente de su templo y una estatua de bronce proveniente del vestíbulo de dicho templo que representaba una vaca en el momento de amamantar a su ternero. En Asur se descubrió una estatua en la que aparece el nombre de Asurbelkala, que parece representar a Istar, y que por sus características parece ser de origen sirio. De ser cierta esta interpretación estaríamos ante una estatua "prisionera" que se habría transportado a Asur para privar de protección a sus fieles (Blanco Freijeiro, 1972, 206-207). De igual modo el rey elamita Shutruknahhunte alrededor del 1200 a.C. traslada a Susa el célebre código de Hammurabi y la estela de Naramsim, nieto de Sargón, junto a otras obras de arte babilonias. Tukulti-Ninurta, rey de Asiria, aplastará la rebelión de Kastilias, que será conducido prisionero a Asur y tras la caída de Babilonia la estatua de Marduk será también llevada a la capital (Blanco Freijeiro, 1972, 193) en un claro intento de apropiarse de la "voluntad" del dios de los babilonios.

En el Palacio Central de Nimrud se hallaron los restos de unos relieves realizados en tiempos de $\mathrm{Ti}-$ glatpileser III y que fueron arrancados por Asardón para trasladarlos a un palacio que nunca fue terminado. Estos relieves muestran a unos soldados que portan en andas a estatuas de dioses de una ciudad vencida, que de este modo quedaban sin protección (Figura 5). Lo más interesante de estos relieves es que el texto de la crónica que separa las escenas esculpidas parece indicar que el rey Tiglatpileser se apiadó de ellos y se los devolvió: "Los sacerdotes erib-biti de los templos de Esagila, Ezida y Emeslam me trajeron los rihati de Bel, Nabu y Nergal.... Yo los adorné con largueza y fueron devueltos a su país". Los dioses son identificados como Adad e Istar (Blanco Freijeiro, 1972, 238). Otro testimonio de devolución de estatuas de dioses "cautivos" lo vemos en Ciro cuando éste, tras proclamarse en Babilonia, el elegido del dios Marduk (539 a.C.) se presenta como libertador de los pueblos sometidos a Babilonia y ordena la devolución de las mencionadas estatuas a sus santuarios originales junto con las poblaciones deportadas, como ocurrió con los judíos que fueron devueltos a Palestina e integrados en la Satrapía de Damasco ordenando también el rey la reconstrucción del templo (I. Esdras, VI, 2-5).

Cuando Susa es la capital del Imperio Persa se traslada a ella el célebre grupo escultórico de los tiranicidas -Harmodio y Aristogitón- obra de Antenore, y que fue robada del ágora de Atenas por los persas cuando éstos conquistan la ciudad en 480 a.C. Pausanias (Hell. Per.I, 8,5) nos dice sobre este asunto: "No lejos están Harmodio y Aristogitón, 
los que dieron muerte a Hiparco [...] De las estatuas, unas son obra de Critias, pero las antiguas las hizo Antenor. Como Jerjes se llevó también éstas como parte del botín cuando se apoderó de Atenas abandonada por los atenienses, Antíoco después las devolvió a los atenienses”. No sabemos si era costumbre estas devoluciones a los vencidos o restituciones a los redimidos. En época romana veremos a Augusto devolver estatuas cultuales arrebatadas por Antonio, pero se piensa que ello es excepcional.

Todavía este modo de adquirir obras estará presente en la conquista romana de Sicilia y del Oriente. En un principio la justificación será la vieja creencia de apoderarse de las divinidades enemigas pero poco después surgirá también el deseo de emularlas. De este modo los conquistadores de Siracusa (212 a. C.), Corinto (146 a. C.) o Atenas (86 a. C.) quisieron no sólo que Roma fuese digna de aquellas capitales orientales, sino que las superase. Sabemos que en el 194 a. C. C. Tito Quintio Flaminino exhibió en su triunfo las estatuas de bronce y mármol arrebatadas a Filipo V de Macedonia, junto con vasos y obras maestras de bronce. Y en el 188 a.C., Escipión trajo de las ciudades griegas del Asia Menor 134 estatuas y en el triunfo de Nobilior, celebrado en el 187 a C. figuraron 285 estatuas de bronce y 250 de mármol procedentes de las colección particular de Pirro, que poseía en Ambracia (Blázquez Martínez, 1978).

A partir de los Flavios, cuyo saqueo y destrucción del templo de Jerusalén se evidencia en los re- lieves del Arco de Tito en Roma, las razzias de obras de arte como botín de guerra dio paso a la tendencia contraria: los emperadores enriquecieron las provincias con abundantes obras de arte, especialmente Adriano, el más erudito en arte de todos los emperadores romanos que engrandeció a Grecia y a otras partes del Imperio. Tal vez el último representante de esta forma de engrandecer ciudades sea Constantino, quien hizo trasladar gran cantidad de estatuas para embellecer su nueva capital: Constantinopla.

\subsection{POR SU VALOR ECONÓMICO Y DE CONTRAPRESTA-} CIÓN.

De Asurubalit (1365-1330 a. C.) a quien los asirios atribuían su renacer, nos han conservado unas cartas halladas en el archivo de Amarna (Blanco Freijeiro, 1972 , 191). Con la primera acompaña unos regalos consistentes en un hermoso carro, un tronco de caballos y una perla de lapislázuli. El rey no pide nada a cambio y sólo recuerda que su padre Eribaadad nunca hizo nada igual. En la segunda carta todo cambia se dirige a Amenofis como "el Gran Rey, tu hermano". Esta vez sus regalos son más numerosos pero ahora espera una contraprestación: una entrega de oro, veinte talentos al menos, "para sufragar la construcción de un nuevo palacio". Esta carta es un claro testimonio de la importancia del valor económico de los objetos que se intercambiaban en señal de hospitalidad los reyes y los poderosos, en esa
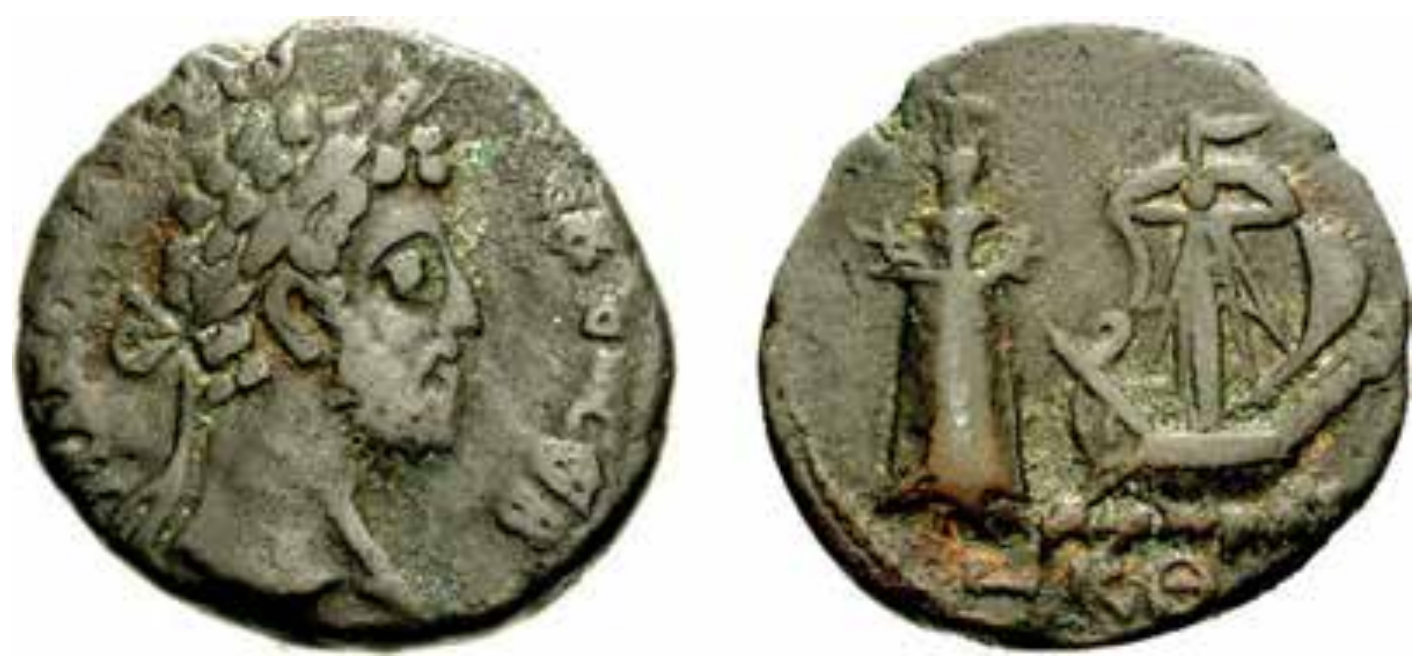

Figura 4. Septem Orbis Spectaculis. Faro de Alejandría. Tetradracma de Cómodo con cabeza laureada en el anverso y en el reverso el faro con la estatua presumible de Helios y una nave aproximándose al puerto (C) Javier Verdugo. 

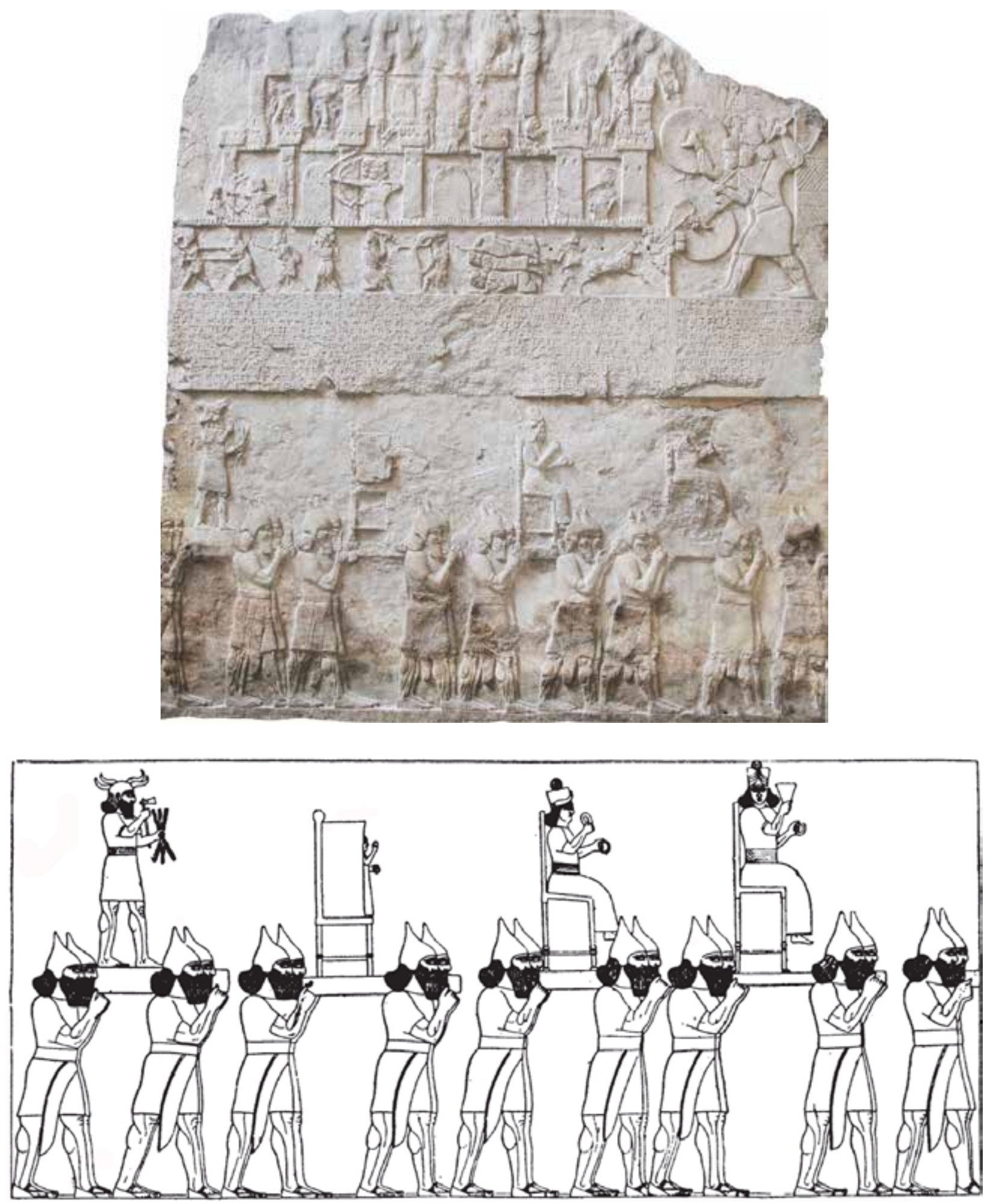

Figura 5. Relieves de Nimrud con el traslado de los dioses de una ciudad vencida () British Museum. Dibujo de Richardson (1849), en Layard, Ninive and its remains (1849) NYPL, ID: 162483 
relación llamada del “don contra don”. Son dones o presentes dados en señal de hospitalidad, agasajando al huésped o al igual con toda una serie de preciados regalos que forman parte a partir de ese momento de su propio patrimonio, a condición de que alguna vez pueda recompensar y tratar de la misma manera al dador. De esta forma se crea un estrecho vínculo, casi sagrado, entre el donante y el receptor convertido en una especie de depositario o poseedor de bienes de otro, poseyendo el corpus pero no el animus. Surge así la necesidad de devolver. Dar, recibir y devolver. El regalo es un reto pues de él se deriva la obligación de contra prestar algo similar o equivalente al donante (Espejo, 1991, 115-124). Si no se puede hacer, además de un deshonor, entraña una obligación de dependencia hacia el donante, de sumisión. Sobre todo si el receptor no posee la capacidad económica para devolver un regalo de igual o superior categoría. En este caso el regalo, el don, es una manera de conseguir el vasallaje. Los objetos son por lo general obras de arte, lujosas y por tanto costosas. De ellos tenemos algunos ejemplos en la Ilíada y en la Odisea. Un vistoso tahalí teñido de púrpura y una aurca, copa de doble asa (Il, 1-216 y ss.). Una crátera labrada de plata y oro obra de Hefestos ( $O d, I V .615$ y ss.). Siete asientos de plata, una crátera de plata, doce mantos, doce tapetes, doce palios, túnicas y cuatro mujeres (Od. XXIV, 274 y ss.). Cuando Telémaco visita a Menelao en Esparta, en busca de noticias de su padre, su anfitrión le ofrece de despedida "tres caballos y un carro hermosamente labrado [...] y una magnífica copa para hacer libaciones" (Od. IV, 589 y ss.). Ante dicho obsequio Telémaco opuso ciertos reparos: "El don que me hagas consista en algo que se pueda guardar. Los corceles no pienso llevarlos a Ítaca [...] Itaca no tiene lugares espaciosos donde se pueda correr, ni prado alguno" (Od. IV, 590-605).

Estos objetos formaban parte del "tesoro" que se conservaba, fuertemente custodiado, y no se "utilizaban", sino que su uso se limitaba a la mera posesión y a servir de regalos a terceros. Precisamente la palabra griega usada para definir el "tesoro" era keimelion, que literalmente significa algo que puede guardarse. En los poemas homéricos el keimelion era de bronce, hierro o de oro, y menos frecuen-

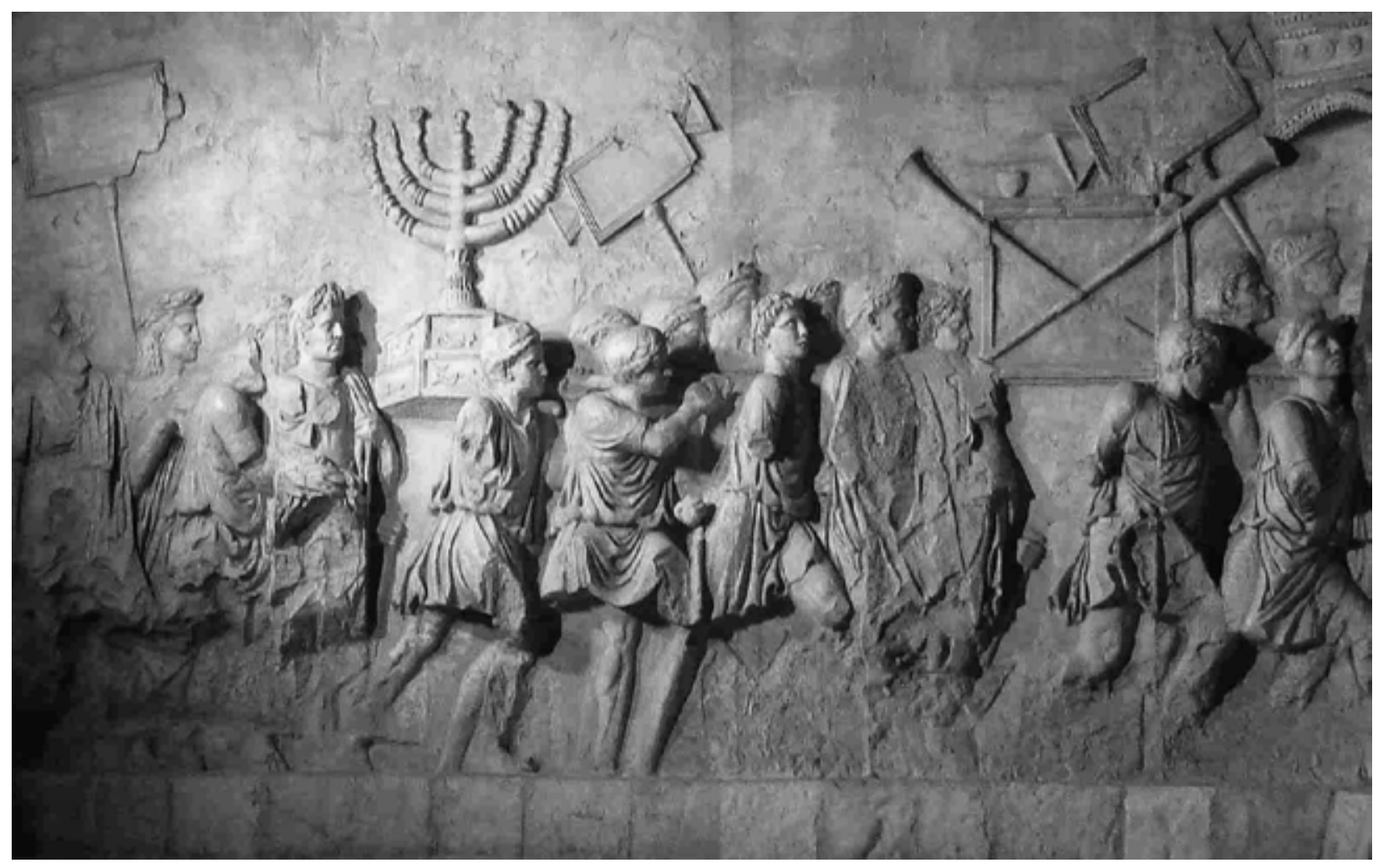

Figura 6. Escena del Arco de Tito en el Foro de Roma, con el triunfo tras la guerra con los judíos. Se aprecian como figuran en el cortejo el candelabro - menorà- y las trompetas de plata que se usaban para llamar a la lucha (C Soprintendenza speciale per $i$ beni Archeologici di Roma. 
temente de plata o hermosas telas y presentaba la forma de copas, trípodes o calderos. Tenía un valor utilitario y ofrecía satisfacción estética pero ninguna de esas funciones podía compararse con el valor que tenían como riqueza simbólica o de prestigio (Finley, 1978, 72). También Agamenón cuando pretende reconciliarse con Aquiles le ofrece reparaciones por medio de presentes, algunos utilitarios como caballos o mujeres cautivas e incluso la mano de su hija Briseida, pero comienza no por éstos sino con un catálogo de piezas propias del "keimelion: siete trípodes no puestos aún al fuego, diez talentos de oro y veinte calderos relucientes" (Il., 121-156). Acrecentar el keimelion es uno de los objetivos príncipes o héroes aqueos, como en la Edad Media sucederá con las "wunderkammers", de los palacios y monasterios. Lo nutrirán de diversos modos: por el comercio, el botín de guerra, el pillaje o el encargo a hábiles artesanos. Ello mismo hace viable la guerra, la piratería y la rapiña como fórmulas “comerciales” que no pasó desapercibida ni a los propios contemporáneos como afirma Fernández Ubiña $(1979,82)$.

Otros testimonios sólo tratan a los objetos por su mero valor económico, tal es el caso de Sargón II de Asiria cuando nos refiere en su relato sobre la conquista de la ciudad de Musasir, en Urartu:

"He saqueado el templo y el palacio de la ciudad y amontonado cuanto a Ursana (el rey) pertenecía: seis escudos de oro que había en las paredes de su casa, a izquierda y derecha, y que tenían un maravilloso resplandor; una grande espada de oro; noventa y seis lanzas de plata; trescientos noventa y tres vasos de plata [...]; cuatro estatuas de bronce que guardaban las puertas; una estatua de Sardur, hijo de Ispuini, rey de Urartu; una estatua de bronce de Argisti, rey de Urartu; una estatua de bronce de Ursa, con el carro, el auriga y los dos caballos..". (Blanco Freijeiro, 1972, 264).

Cuando los objetos tenían oro y piedras preciosas, existía un interés por apoderarse de estas riquezas. Numerosas obras de arte han terminado fundidas por los materiales de que estaban hechas. Heródoto (Hist I, 193-194) cuenta como Jerjes I, tras la conquista de Babilonia, suprimió el culto a Marduk y trasladó a su capital la estatua sedente del dios Baal, que estaba hecha enteramente de oro y valorada en 800 talentos. Es esta la forma de interés por los objetos como mero objeto de expolio.
7.3 PoR SUS CUALIDAdES ARTÍ́STICAS O SU FUNCIÓN.

La religiosidad egipcia y el concepto de la vida de ultratumba generan la necesidad de dotar a las tumbas de un amplio y rico mobiliario al servicio del difunto. Esta necesidad hace aparecer una importante artesanía altamente especializada. Las copas de alabastro halladas en Saqqarah son un ejemplo del prestigio de estas piezas por su valor artístico que aún marcadas con los nombres de los reyes tinitas fueron empleadas nuevamente por Djeser y amontonadas en las galerías construidas debajo de la pirámide escalonada (Drioton-Vandier, 1973, 127). También para el servicio de las tumbas los muebles, joyas, armas y placas de marfil como las encontradas en Abidos en época tinita son testimonio del grado de desarrollo alcanzado por los artesanos egipcios, progreso que se acrecienta en el Imperio Antiguo en la tumba de Hetepheres madre de Keops, donde el mobiliario y los objetos de tocador muestran las habilidades señaladas (DriotonVandier, 1973, 165). También debemos destacar la fabricación de sarcófagos de madera pintados, desde finales del Imperio Antiguo o las colecciones de joyas halladas en las tumbas reales del Imperio Medio, que no son superadas en armonía por la joyería del Imperio Nuevo, que son más grandes y complicadas antes que leves y armoniosas, como ocurre con las colecciones de armas y joyas encontradas en la tumba de la reina Ahhotep-comienzos de la XVIII Dinastía- o las halladas en el Serapeum de Ramsés I (Diotron-Vandier, 1973, 422). Finalmente en el Imperio Nuevo se alcanza un notable desarrollo en la fabricación de mobiliario funerario, destacando el trono y el cofre hallados en la tumba de Tutankhamon. Estos objetos fueron muy apreciados tanto por su función funeraria como por su acabado, confección y empleo de materiales costosos y preciosos que los hizo especialmente atractivos para una de las actividades más lucrativas de Egipto: el robo de tumbas.

En la Edad del Bronce Tardía (1500-1100 a.C.) de Grecia, en la llamada sociedad micénica, los señores de Pilos, Orcómenos, Micenas, Tirinto y otras fortalezas vivían en palacios y se rodeaban de objetos de marfil, oro y sobre todo bronce, trabajados por artesanos. Éstos, de origen cretense o local, bajo la supervisión de los administradores de palacio retiraban pequeñas cantidades de bronce y la devolvían en forma de armas y otros objetos de lujo, siguiendo modelos fijos. Algunas tablillas como las de Pilos nos dan testimonio de más de 193 
artesanos trabajando en un área no muy extensa (Starr, 1982, 40).

Ya nos hemos referido al uso de dichos objetos valiosos y artísticos en las relaciones de dependencia o de hospitalidad, en el "don contra don". Tanto la Odisea como la Ilíada nos presentan testimonios de estos "regalos" como los recibidos por el joven Telémaco. Los trípodes de bronce son mencionados en los poemas homéricos como bienes de prestigio que servían de moneda-utensilio.

Con el desarrollo de las tecnologías de la metalurgia, adquieren un gran valor los objetos realizados en bronce. De modo que son apreciados por la materia en que están realizados, por su fortaleza y utilidad. Precisamente la consecución del metal romperá el carácter autárquico del oikos de la Grecia arcaica cuyo suministro será fundamentalmente extranjero. Como consecuencia de la importancia del bronce y de los metales en general se considera hermoso lo que está hecho de forma especial y con materiales cuanto más valiosos mejor, quedando asociada la belleza al valor.

Ya hemos afirmado que se recurre a la piratería $y$ a la rapiña para conseguir el metal y objetos, pero también al comercio para conseguir los metales aunque partiendo del desprecio a aquél que se realiza con el ánimo de lucro personal. Este comercio con fines lucrativo será realizado especialmente por los fenicios, quiénes como todo comerciante gozarán de una mala reputación.

Los objetos fabricados por los fenicios son tenidos en los poemas homéricos como poseedores de un gran valor. Homero los admira como excelentes artífices. Las mercancías que venden son vasos metálicos, escudos y telas. Así Aquiles (Il., XXIII, 74) ofrece como premio de un certamen una crátera de plata fabricada en Sidón; Menelao (Od. IV, 615) regala a Telémaco otra crátera de plata, regalo del rey de Sidón y que es tan perfecta que considera "obra de Hefaistos". Estas crateras debieron ser parecidas a las halladas por Layard en el palacio de Asurbanipal en Nimrud (Blanco Freijeiro 1971, 28).

Junto a estas piezas los poemas homéricos describen otras entre las que destacaríamos por su interés y por el carácter emblemático que la misma ejercería sobre los antiguos el llamado escudo de Aquiles (Il., XVIII 478 y ss.): "Hizo lo primero de todo un escudo grande y fuerte/de variada labor con triple cenefa brillante y reluciente,/ provisto de una abrazadera de plata. Cinco capas tenía el/escu- do, y en la superior grabó el dios muchas artísticas/ figuras, con sabia inteligencia”.

También son dignos de mención los extraordinarios sarcófagos como los aparecidos en Gades en 1887 y 1980, respectivamente.

En el Occidente romano, la toma de Siracusa, y su posterior saqueo, es para algunos (Bianchi Bandinelli, 1970, 36) el momento crucial del contacto de Roma con el arte helenístico. Plutarco en la biografía de Marcelo, (Marcel., 21) se hace cargo de ese desinterés por los romanos hacia estas obras y que aquél con ello se ganó la estimación del pueblo: "Se llevó de Siracusa la mayor parte y las más bellas obras de arte para las ceremonias de su triunfo y para ornato de la ciudad. Roma, en efecto, no poseía ni reconocía anteriormente ninguno de estos objetos de lujo y de refinamiento, ni se complacía ante las obras graciosas y elegantes [...] Así Marcelo se ganó la estimación del pueblo por haber enriquecido la ciudad con un espectáculo de placer, de gracia helénica y de aspectos variados del arte”.

Estos actos de Marcelo no gustaron a algunos romanos pues entendían que los mismos ofendían a la pietas debida a los dioses de otros pueblos y por consiguiente no encajaban en las mores maiorum. Toda vez que daba la impresión de lucir como prisioneros en su triunfo no solo hombres, sino también dioses. A Marcelo se le reprochó también que con estas acciones indujera al pueblo, acostumbrado a combatir y cultivar sus campos, a la ociosidad y a inducirlo a discutir de arte y artistas. Plutarco sigue su relato y contrasta este disgusto con el buen hacer de Fabio Máximo: "no trajo ni arrebató nada parecido, después de la toma de Tarento; por el contrario, se adueñó de todas las riquezas y dinero, dejando las estatuas en su lugar, diciendo, según la tradición: Dejemos a los tarentinos estos dioses tan irritados".

La opinión de Plutarco, que escribió mucho tiempo después de estos hechos y que podía estar interesado en "hacer resaltar la simplicidad rústica de los viejos romanos” (Bianchi Bandinelli, 1970, 36), debió estar asentada en una tradición antigua y genuinamente romana. Tito Livio (XXV, XL, I-3), también se hace eco de ella al afirmar que la toma de Siracusa señala "el comienzo de la admiración por las obras de arte de los griegos".

Pero no sólo Marcelo trajo de Siracusa obras de arte, sino también otros objetos curiosos como dos esferas celestes atribuidas a Arquímedes suceso que 
conocemos por Cicerón (De Republica I, 21): “Un día que Cayo Sulpicio Gallo fue a visitar a Marco Marcelo [...] ordenó éste que se le trajera el globo o esfera celeste que su abuelo había traído de Siracusa, cuando conquistó esta opulentísima ciudad (212 a.C.). Aquel globo fue lo único que se llevó a casa del inmenso botín capturado en la ciudad. He oído mencionar muchas veces esta esfera a causa de la fama de Arquímedes, pero cuando la vi personalmente no me causó gran admiración, pues ya me era conocida otra esfera celeste, construida también por Arquímedes, y que el propio Marcelo colocó en el templo de la Virtud. Ésta última es más bella y mucho más conocida de la gente". Esta esfera celeste que Marcelo conservó en su casa era un objeto excepcional, que mediante un complicado mecanismo de relojería reproducía con gran exactitud los movimientos de los cuerpos celestes. Este artefacto nos indica el interés que para los romanos del siglo III a. C. tenía la astronomía y las teorías espirituales de Posidonio de Apamea o de Metrodoro de Escepis (Gómez de Liaño, 1998, 29-36). Es pues a finales del siglo III a. C. cuando los romanos comienzan a descubrir que el arte es algo más que una técnica y que el mismo tenía valor. El sucesor de Metelo, el cónsul Mummio, quién conquistó, saqueó y destruyó la rica ciudad de Corinto; según cuenta Aurelio Víctor (De viris ilustribus, LXI): "llenó Italia de estatuas y de cuadros conquistados en el saqueo de Corintio sin que se llevase ni uno solo a su casa". También vendió en pública subasta muchos de los tesoros, y se sorprendió del extraordinario precio que ofreció Attalo de Pérgamo por un cuadro antiguo que representaba a Dionisos. Mummio según nos dice Plinio (Nat. His, XXXV, 24) sospechando cualquier virtud oculta en esta pintura la hizo retirar de la venta. Según la tradición esta oferta había alcanzado los 600.000 denarios unos 190 kilogramos de oro. La incredulidad y sospechas de Mummio serían propias de toda la clase dirigente de su tiempo más cercana a las críticas que recibió Marcelo. Ello no impide que no existieran en Roma intelectuales que supiesen que Arístides de Tebas, el autor de dicho cuadro, había sido el fundador de la escuela de pintura ática a comienzos del siglo IV (Bianchi Bandinelli, 1970, 37).

El cónsul Marco Fulvio, conquistador de la Etolia y de la Arcania, trajo a Roma 285 estatuas de bronce y 230 de mármol que fueron consagradas en el Aedes Herculis Musarium. Las divinidades tutelares de este edificio estaban representadas por un grupo dedicado a las Musas, que procedía de Ambracia, de las que se poseen algunas copias y por un Hércules de Lisipo traído del templo de Hércules de Alizia (Wescher, 1988, 6). Lucio Emilio Paulo, vencedor en la batalla de Pidna (168 a.C.) contra el rey Perseo de Macedonia, portó en su triunfo 250 carros llenos de tesoros recogidos en toda Grecia como "recompensa" por haberla liberado del yugo macedónico. Entre las esculturas figuraba según el testimonio de Plinio (NH, XXXIV, 54) una estatua de bronce de Fidias, que representaba Atenea (Minerva en el texto de Plinio). Los objetos fueron consagrados al templo de la Fortuna. Estos acontecimientos son referidos por Polibio, que formaba parte de los rehenes que los romanos llevaron a Roma y escogidos de los pertenecientes a rangos sociales elevados. Plutarco y Estrabón también cuentan estos sucesos.

En los años 148 al 146 a.C. tuvo lugar el triunfo de Quinto Cecilio Metelo, y los ciudadanos romanos pudieron admirar otro grandioso botín: las esculturas de bronce, marfil y mármol tomadas por Metelo a los macedonios y que fueron consagradas a los templos de Juno y de Júpiter en el Campus Martius. De los testimonios de los escritores antiguos sabemos que entre las estatuas figuraban dos estatuas originales de Praxiteles, una Diana y un Esculapio, más también un Júpiter y una Hera de Policleto, mientras el templo de Júpiter se enriqueció en esta ocasión con un Zeus de Praxiteles, y un grupo de figuras con un Pan de Heliodoro y una Venus en el baño de Policarmo.

Hasta la época imperial la ley ordenaba que las obras de arte conquistadas en acciones de guerra pertenecieran al Estado y debían servir únicamente para embellecer la ciudad. Es probable que de ellas se llevara un inventario en el Tabularium, en calidad de archivo del Estado, en el que se especificaría el lugar de su colocación. Todo esto parece desprenderse de la signatura $-L \cdot V I \cdot P \cdot L \cdot X X I X$ - que figura en la escultura en bronce del Museo Nazionale de Arte Romano de Roma, de época republicana, conocido como "Príncipe helenístico", fechable entre 162-150 a. C., si damos por buena la interpretación de Blanco Freijeiro $(1971,302)$ siguiendo a Krahmer (1923-1924) de que se trata de un retrato de Demetrio I de Siria, que permaneció en Roma durante esos años como rehén. Distinta interpretación es la señalada por Zanker (1992, 20-21) quien apoya la idea de que sea la representación de un general romano, fechándolo hacia el 180-150 a.C. 
Según parece existía la obligación de depositar en el erario todas las esculturas confiscadas, por alguna razón legal. Precisamente del incumplimiento de este deber acusó Cicerón (In Verrem) a Verres en la segunda de sus oraciones, a quién imputó el haberse enriquecido personalmente como gobernador del Asia Menor. Verres había despojado de sus estatuas a templos en Tenedo, Kyo, Alicarnaso, Eritreía y de forma especial algunas del Heraión de Samos. Especial relieve tiene la acusación de la sustracción de Mesina de una copia de la estatua de Eros, copia de la que había dedicado la hetera Friné, amante de Praxiteles, en su ciudad natal de Tespias en Beocia (Cicerón, De signis, 4). En relación con Verres es significativo el comentario de Plinio $(\mathrm{NH}$, XXXIV, 6-7) por el que nos informa de la afición que aquel tenía de esculturas realizadas con bronce de Corinto, que era el más apreciado, y sobre su proscripción por Antonio por no haber accedido a cederles precisamente esos bronces. También el propio Cicerón en las Verrinas alude a esta afición de Verres.

Sila, de quien Pausanias (Hell.Per. IX, 33,6) dice que tuvo con los atenienses, tebanos y orcomenios "un trato brutal y extraño al carácter romano", hizo transportar a Roma columnas corintias del templo de Zeus de Atenas para sustituir a las del templo de Júpiter en el Capitolio, que habían sido destruidas en la guerra civil, así como los escudos del pórtico de Zeus Eleuterio, entre los que se encontraba el de Cidia el joven héroe ateniense de la lucha con los gálatas (Pausanias (Hell. Per. X, 21,6). En el 86 Sila se adueñó de la estatua de marfil de Atenea Alalcómenas, enviándola a Italia, según testimonio de Pausanias (Hell.Per. IX, 33,6) Sila, ofrendó al Helicón una estatua de Dioniso, obra de Lisipo, pero como afirma Pausanias (Hell. Per. IX, $30,1)$ hizo la ofrenda no de sus propiedades, sino que se la quitó a los minias de Orcómeno y añade: "esto es lo que llaman los griegos adorar a los dioses con incienso ajeno". En su admiración por el arte griego los romanos no se limitaron a la época clásica, desarrollando al final de la República un particular gusto por el arte arcaico, de lo que son una prueba las obras romanas arcaizantes. En 1959 en el Pireo se descubrió un grupo de estatuas de bronce de cronología diversa, entre las que se encontraba una figura de un kouros. Las estatuas se hallaron entre las ruinas de un antiguo almacén del puerto destruido por un incendio, que en opinión de Wescher $(1988,8)$ podrían proceder de uno de los

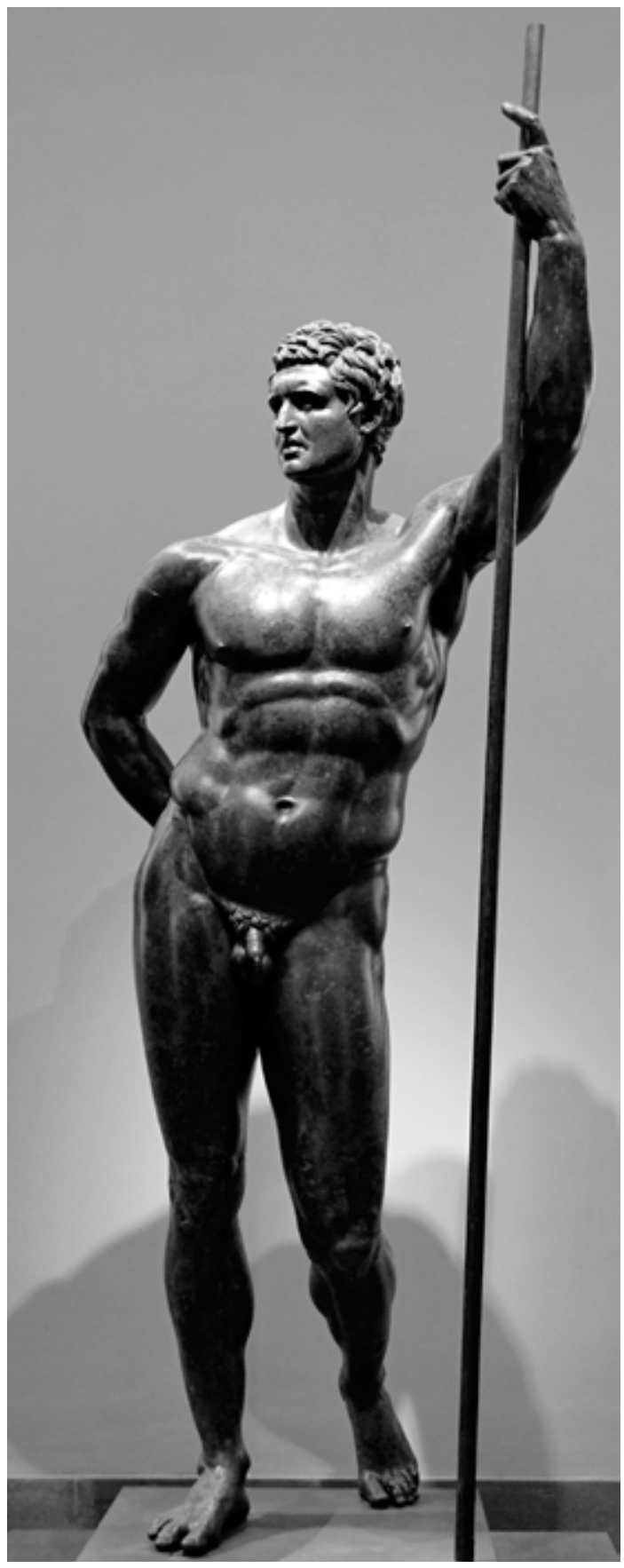

Fig. 7. El Príncipe helenístico fue descubierto en 1885 en el Esquilino, lugar donde se alzaban las Termas de Constantino. Junto a él apareció otra estatua en bronce, la llamada Púgil en reposo, de la que es autor Apolonios Néstoros, que a su vez lo es del famoso Torso de Belvedere, pues ambas aparecen con su nombre. Es posible que la estatua del Príncipe y la del Púgil, constituyeran un grupo cargado de intención en el que el primero representase tal vez a Polux y el segundo al boxeador espartano Amilo, amigo de los Dioscuros ( $)$ Museo Nazionale Romano Palazzo Massimo. 
cargamentos que Sila ordenó enviar a Roma tras el saqueo de Atenas.

También Marco Antonio tomó de Samos unas estatuas que representaban a Zeus, Atenea y Hércules. Estas estatuas fueron devueltas a la ciudad por Octavio tras la derrota de Antonio en Actium, a excepción del Zeus que fue enviando por éste al Capitolio. Asimismo y para castigar a los habitantes de Mantinea, que habían permanecido fieles a Antonio. Octavio sustrajo del templo de Atenea de Tegea la famosa estatua de esta diosa allí colocada y la colocó en la entrada del nuevo Foro en el Capitolio. Si aceptamos la noticia que de ella nos da Pausanias (Hell. Per.I, 430) había sido obra de Endoios y era toda ella de marfil. Pausanias en su libro VIII hace una serie de consideraciones sobre la costumbre de saquear y trasladar obras de arte por parte de los romanos. Así nos comenta (Hell. Per.VIII, 46) cómo la antigua imagen de Atenea Alea que estaba en el santuario de Tegea, y con ella los colmillos del jabalí Calidón, fueron llevados a Roma por Augusto, tras vencer a Antonio a cuyo lado combatieron los de Mantinea y que según cuenta el propio Pausanias estaba situada a la entrada del foro hecho por Augusto. Era toda de marfil y obra de Endeo.

También nos refiere que uno de los colmillos del jabalí se rompió y que se conservaba en un santuario a Dioniso en los jardines del emperador, y que su perímetro era de media braza. Pero Pausanias disculpa a Augusto diciendo que con ello sólo ejercía una antigua costumbre de llevarse ofrendas e imágenes de dioses de los vencidos.

A continuación enumera como esa costumbre arranca desde la toma de la misma Ilión, donde Esténelo, hijo de Capaneo, recibió la xoana de Zeus Herceo. También nos informa de cómo Antifemo, fundador de Gela en Sicilia, después de saquear la ciudad de los sicanos, Ónface, traslado a Gela una imagen hecha por Dédalo, también esto está recogido por Heródoto (VII, 153) o de cómo los de Cícico se llevaron de Proconeso una imagen de la madre Dindimene, que era de oro, con el rostro hecho de dientes de hipopótamo. Y si eso realizaban los griegos, también los persas según nos continúa relatando. De este modo, Jerjes, aparte de lo que se llevó de Atenas, cogió de Braurón una imagen de Atenea Brauronia, y en represalia a los milesios por, en su opinión, haber actuado con cobardía se apoderó del Apolo en bronce de Bránquidas.

Egipto será también tierra de promisión de obras de arte para Roma. Así Octavio tomó de allí los tres obeliscos que hoy se encuentran en la Piazza di San Giovanni a Laterano, Piazza del Popolo y Piazza de Montecitorio. Originalmente los obeliscos fueron colocados en el Circo Máximo y en el Campus Martius, su transporte en trirremes debió ser una operación no exenta de dificultades a la vez que un instrumento de propaganda política (Parodi, 2006, 89-102).

Uno de los últimos testimonios de traslados es la piedra negra de Emesa en Siria, símbolo del dios Helios, que Heliogábalos, para enfatizar su intencionalidad ante su propuesta de culto al sol, hizo llevar al templo del Sol en Roma, junto a otras piezas de gran valor simbólico, como el fuego sagrado de Vesta, el Paladio, la piedra de la magna mater y los escudos sagrados de Diana que estaban en Laodicea de Siria (Roldán, 1989, 442). Tras la muerte de Heliogábalos, y el rechazo de los romanos a los rituales del Sol Invicto, la piedra negra fue devuelta a Siria.

\subsection{POR SU CARÁCTER DE RELIQUIA.}

Todas las sociedades han rendido culto a los muertos. La palabra reliquia tiene su origen en el latín reliquae-arum, "sobras, restos" de un muerto, que deriva de reliquus, "lo que permanece". Literalmente hace referencia a aquello que queda de algo, y se aplica especialmente a los restos de una persona muerta. El culto a las reliquias no es un fenómeno ligado exclusivamente al cristianismo aunque, evidentemente, ha sido con la Iglesia cuando este culto ha conseguido mayor difusión espacial y temporal. Antes del cristianismo existe un culto a las reliquias en los llamados pueblos primitivos, y a ello hay que asociar también el particular tratamiento dado a los huesos y cráneos del enemigo muerto o sacrificado, o la costumbre de mantener en la casa los huesos de los difuntos. En Grecia y en el culto a sus héroes (Pfister, 1909, 331-381), debemos situar el precedente de la devoción a la reliquias de santos y mártires cristianos.

Era costumbre entre los griegos rendir homenaje a determinados objetos que habían pertenecido a los héroes e incluso a restos humanos de éstos. De este modo, hay despojos corporales, como los huesos gigantescos atribuibles a Teseo, y objetos de usos: armas, instrumentos musicales, ornamentos, viviendas o palacios y hasta restos de animales vinculados a los héroes. La lanza de Aquiles se hallaba en el templo de Atenea en Phaselis (Paus. Hell. Per. III 3,8); la de Meleagro en el templo de Apolo en Sykion (Paus. Hell. Per. II 7, 8); el yelmo y la 


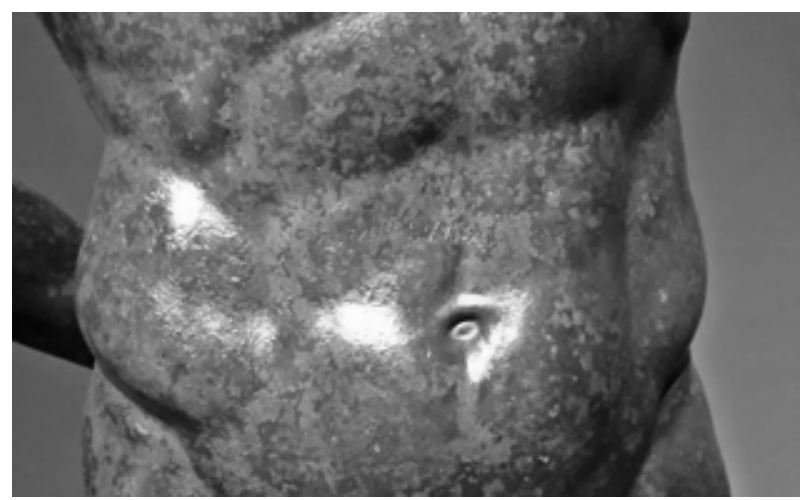

Figura 8. Escultura de bronce heroica, que conserva la signatura $L \cdot V I \cdot P \cdot L \cdot X X I X$ de un probable inventario público () Museo Nazionale Romano Palazzo Massimo.

lanza de Odiseo en el templo de la Diosa Madre en Engyon (Plut. Marcell. 20), entre otros muchos. También, cómo no, existían reliquias vinculadas a las divinidades. De este modo y, al igual que en el cristianismo, las hay directamente ligadas a Cristo, tales como la Cruz o la Sábana Santa, en la Antigüedad tenemos numerosos ejemplos de reliquias de las deidades olímpicas. Así, en Delfos, se mostraba la tumba de Dionisos y la roca que el propio Cronos se habría tragado en lugar de su hijo Zeus. Por otra parte, existía la costumbre en Grecia de asociar las tumbas de los héroes o personajes famosos a santuarios o templos donde se les veneraba y visitaba y de todo ello, han llegado a nosotros innumerables testimonios como el de Árcade referido por Pausanias (Hell. Per. VIII, 8.3). La mayoría de esos testimonios presentan un denominador común, y es que en todos ellos se atestigua la presencia de un oráculo que indica donde están las reliquias del héroe, ordena su traslado y que le sea erigido un recinto sagrado. Este es el caso del referido por Pausanias para el oráculo de Delfos, que ordenaba: "Menalia es invernal, allí yace/Árcade, del que todos reciben su nombre./Donde hay encrucijadas de tres, cuatro y cinco caminos./Allí te ordeno que vayas y con ánimo propicio/cojas a Árcade y lo lleves a tu amable ciudad,/y allí constrúyele un recinto sagrado y prepárale ofrendas".

Los de Mantinea ejecutaron los deseos del oráculo y lo instalaron en el templo de Hera, junto al altar de la diosa y a su sepulcro lo llamaron "altar de Helio".

Así se conocen santuarios en Egipto ofrecidos a cada uno de los miembros mutilados de Osiris e, incluso, el caso peculiar del dios Apis que poseía su cementerio particular. También, en época adrianea, se llegaron a consagrar, en Mantinea, templos a Antinoo, en este caso por su origen bitinio, es decir arcadio como los mantineos. En su honor se celebraban misterios y juegos.

\section{CONCLUSIÓN}

El interés por el pasado se formaliza, a través del conocimiento de los hechos pretéritos; de los sucesos y sus protagonistas y de la observación de los restos materiales del pasado. Estos sucesos en una primera etapa son transmitidos oralmente mediante la recitación de las hazañas de seres divinos y de héroes en forma de mitos. A esta fase le sucede una segunda de racionalización del conocimiento por medio de la "autopsia" o análisis contrastado de los sucesos reales acaecidos. Surge así la historia y la etnología. Junto a esta forma aparece el análisis directo y descriptivo de los restos materiales con el viaje o la "periégesis". Fruto de esa primera observación asistimos a un interés por construcciones que están cargados de admiración y que se sitúan, en un primer momento, bajo el concepto de maravilla o spectaculis y aparece en el imaginario, por primera vez, la conciencia de monumentos o construcciones que son excepcionales: Septem Orbis Spectaculis. A esta idea de maravilla se une también la de memoria. Y de este modo numerosos escritores antiguos, como Pausanias o Plinio, describen obras de arte, templos, lugares o construcciones ligadas a la divinidad, héroes o hazañas, que poseen valores que los hace dignos de ser conservados y admirados. Surge así la necesidad de viajar para conocerlos. Aparece también un interés por los objetos como botín de guerra con una doble intención: religiosa, consistente en apropiarse de las divinidades y someterlas a las propias y económica, por su estética y valor. Los objetos son exhibidos ante el pueblo vencedor que en el caso de Roma forman parte de su propio patrimonio.

Bibliografía

Ashley, M., (1970), The seven Wonder of the world, Macmillan.

Bianchi Bandinelli, R. (1971), Roma el fin del arte antiguo. El arte del Imperio romano desde Septimio Severo hasta Teodosio I, Madrid.

Blanco Freijeiro, A. (1971), Arte griego, CSIC, Madrid.

- (1972), Arte antiguo del Asia Anterior, Universidad de Sevilla, Sevilla. 
Blázquez Martínez, J.M. (1978), "El comercio de obras de arte en la Hispania Romana”, Goya, 143, 254-265.

Bloom, H. (2001), El canon occidental, Anagrama, Madrid.

Buxton, R. (2000), El imaginario griego, Akal, Madrid.

Cantino Wataghin, G. (1984), "Il rapporto con l'antico fra mito, arte e ricerca", Memoria dell'antico nell'arte italiana (a cargo de Salvattore Settis), Vol. I, Uso dei classici, Torino, 169-217.

Daniel, G. (1967), Historia de la Arqueología de los anticuarios a $G$. Childe, Alianza editorial, Madrid.

Drioton, E., y Vandier, J.(1973), Historia de Egipto, Editorial Universitaria, Buenos Aires.

Eliade, M. (1972), El mito del eterno retorno, Alianza Editorial, Madrid.

Espejo Muriel, C. (1990), "Variante sexual en rito de hospitalidad griega", Florentina Iliberritana, 1, 115-124.

Fernández Ubiña, J. (1979), "Aspectos sociales de Grecia Arcaica”, Clases y luchas de clases en la Grecia Antigua (C.Mossé, P. Vidal Naquet, J. Fernández Ubiña, y C. González Román, Coords.), Akal, Madrid, 79-102.

Finley, M.I. (1978), El mundo de Odiseo, Fondo de Cultura Económica, México.

García Moreno, L.A. y Gómez Espelosín, J. (1996), Relatos de viajes en la literatura griega antigua, Alianza Editorial, Madrid.

Gómez de Liaño, I. (1998), El círculo de la sabiduría, Siruela, Madrid.

Harmand, J. (1985), La guerra antigua, de Sumer a Roma, Sarpe, Madrid.

Herrero Ingelmo M.. C. (1994), "Introducción”, Pausanias. Descripción de Grecia, Madrid, 7-77.

Jaeger, W. (1988), Paideia, Fondo de Cultura Económica, Madrid.

Le Goff , J.

(1991), El orden de la memoria. El tiempo como imaginario, Paidós Básica, Barcelona.

(1996), Lo maravilloso y lo cotidiano en el Occidente Medieval, Gedisa, Barcelona.

Kirk, G. S. (2002), La naturaleza de los mitos griegos, Paidos, Barcelona.

Kostof, S. (1988), Historia de la Arquitectura, Alianza Forma, Madrid.

Maravall, J.A. (1986), Antiguos y modernos,
Alianza Editorial, Madrid.

Marinatos, Sp. (1969), Some words about the Legend of Atlantis, Museo de Atenas, Atenas.

Marrou, H.I. (1985), Historia de la educación en la Antigüedad, Akal Universitaria, Madrid.

Morgan, L.H. (1971), La sociedad primitiva, Ayuso, Madrid.

Onians, J. (1996), Arte y pensamiento en la época helenística: la visión griega del mundo (350 a.C.-50 a.C), Alianza Editorial, Madrid.

Parodi Álvarez, M. (2006), "La razón de la sinrazón: Cayo César, el obelisco y las lentejas”, Economia de prestigio versus Economía de mercado (G. Chic, Ed.), Padilla Libros, Sevilla, 89-102.

Pfister, F. (1909), Der Reliquienkult im Altertum, Gieben.

Philips, E.D. (1964), “The Greek Vision of Prehistory”, Antiquity 38/151, 171-178.

Plácido Suárez, D. (1997), "Las intervenciones del poder en la imagen del Agora de Atenas", Arte y Poder en el Mundo Antiguo (Domínguez, A. y Sánchez, C., Eds.), Universidad Autónoma de Madrid, Madrid, 177-188.

Ramírez Domínguez, J. A. (1983), Construcciones ilusorias. Arquitecturas descritas, arquitecturas pintadas, Alianza Editorial, Madrid.

Robert, C. (1904), Pausanias als Schrifteller, Weidmann, Berlín.

Roldán, J. M., (1989) El Imperio Romano. Siglos I-III, Madrid.

Vidal-Naquet, P. (2006), La Atlántida. Pequeña historia de un mito platónico, Akal, Madrid.

Starr, Ch. G. (1982), “ Nacimiento y decadencia del mundo micénico”, La sociedad micénica $(\mathrm{M}$. Marazzi), Akal, 38-50.

Verdugo Santos, J. (2015), "La formación del concepto de tutela del patrimonio histórico en la Antigüedad: Monumento y objeto arqueológico en el Derecho Romano", Revista de Derecho romano, $25,-56$.

Waters, K.H. (1996), Heródoto el historiador. Sus problemas, metodo y originalidad, Fondo de Cultura Económica, México.

Wescher, P. (1988), I furti d'arte. Napoleone e la nascita del Louvre, Einaudi, Torino.

Zangger, E. (1992), The Flood from Heaven. Deciphering the Atlantis Legend, Nueva York y Londres.

Zanker, P. (1992), Augusto y el poder de las imágenes, Alianza Editorial, Madrid. 